Bull. Fac. Agric., Cairo Univ., 59 (2008):259-272.

\title{
TRAINING NEEDS FOR AGRICULTURAL EXTENSION WORKERS IN THE FIELD OF RATIONALIZING IRRIGATION WATER UTILIZATION AND PRESERVATION OF WATER RESOURCES FROM POLLUTION IN DAKAHLYA GOVERNORATE
}

(Received: 6.5.2008)

\author{
By \\ Z. H.H. Magd \\ Rural Sociology and Agriculture Extension Department, Faculty of Agriculture, Cairo \\ University, Egypt
}

\begin{abstract}
This study investigated the training needs for Agriculture Extension workers in the field of rationalizing irrigation water utilization and preservation of water resources from pollution, and to study the relationship between their total degree of training needs and some independent variables. It was conducted in Dakahlya Govemorate. A sample of (200) persons was selected randomly. A questionnaire was designed and pretested for collecting the data through personal interviews. Percentages, averages, range, standard deviation and Pearson's correlation in addition to chi-square test were used for data presentation and analysis.

The important results of the study are as follows:

1- About $(45.5 \%)$ of the respondents training needs level is moderate, and (33.5\%) training needs level is high.

2- The main information sources in this study are Agriculture Extension Journal (69.5\%) and Extension bulletins $(67.5 \%)$.

3- About (74.8) of the respondents do not have training in the field of irrigation water rationalizing.

4- The main respondents suggestions related to the development of training level in this field are specific training programs in irrigation water rationalizing $(91 \%)$, foundation of specific extension news in the field of modern methods of irrigation water rationalizing (88\%) and specific trainers in irrigation water $(79 \%)$.

5- The main training programs of requirements are irrigation water rationalizing utilization methods (38\%), water amounts and water consuming for different crops (27.6\%) and modern irrigation methods $(23.2 \%)$ of the total respondents.

6- Related to the Extension activates practical's, (49.5\%) of the researches have field visited and $(34.5 \%)$ have Extension debate.

7- There are a significant relationships at 0.01 level between the total degree of knowledge training needs of respondents and each of the following:- education qualification, numbers of courses in Extension, soil and water, practical's of agriculture activities, number of agriculture training programs, degree of using information sources, constrains facing degree during advice the farmers. There are significant relationships at 0.05 levels between the total degree of knowledge training requirements of respondents and each of the following: specific education, presents and numbers of training programs and cosmopolitans.

8- The main constrains facing the respondents are low response of farmers towards the irrigation water rationalizing recommendation $(49.6 \%)$ and high cost of modern irrigation water methods $(46.3 \%$ ) of the total respondents. The respondents suggestions to solve this constrains are applied agriculture extension fields and experiments (33\%) and increasing of specific extension pollution in irrigation water rationalizing, amount of irrigation water and typical irrigation methods (26.4\%).
\end{abstract}

Key words: extension workers, rationalizing irrigation water utilization, training needs. 


\title{
الاحتياجات التدريبية للمرشدين الزراعيين في مجال أساليب ترشيد استخدام مياه الري

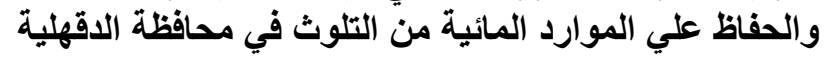

\author{
زينب حسن حسن مجد \\ قسم الاجتماع الريفي والإرشاد الزراعي ـ كلية الزر اعة - جامعة القاهرة-مصر
}

\begin{abstract}
ملخص التزري
استهدفت هذه الدراسة تحديد درجة الاحتياج التدرييي المعرفي للمرشدين الزراعيين في مجال أساليب
\end{abstract}

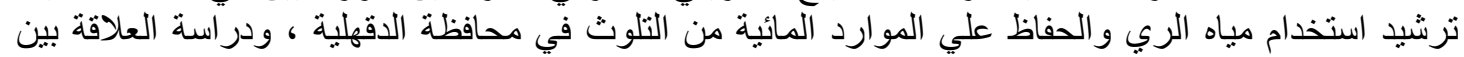

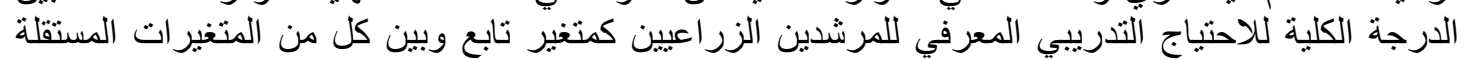

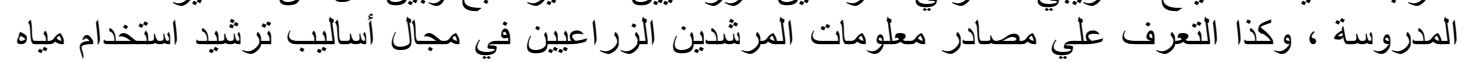

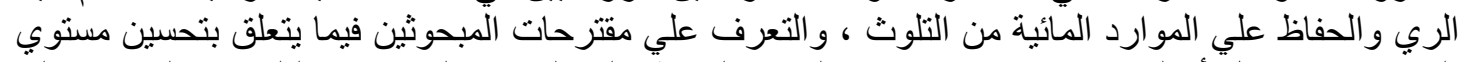

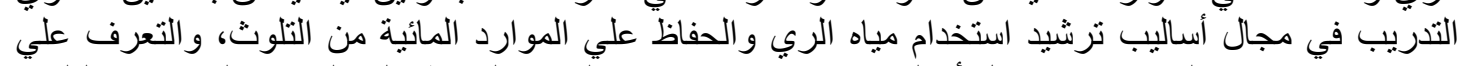

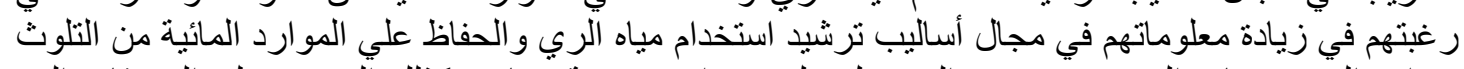

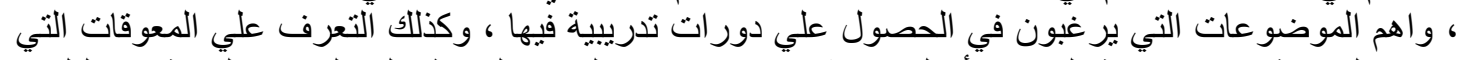

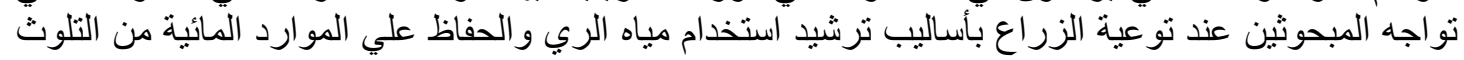

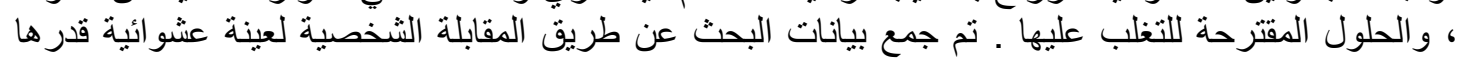

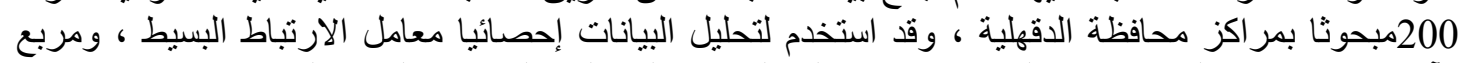

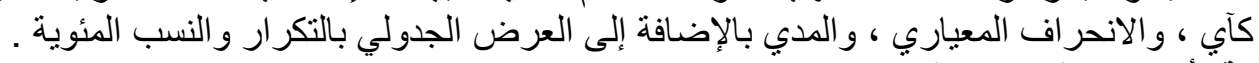

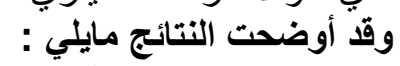

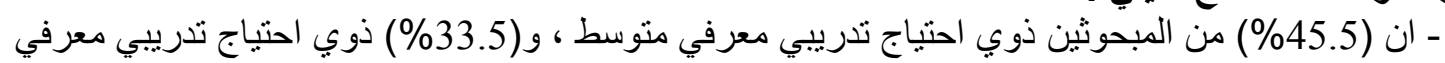

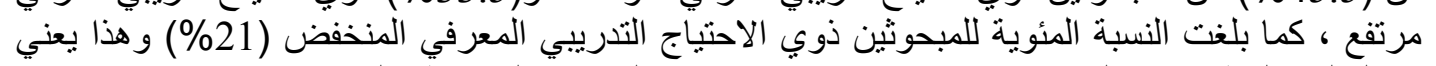

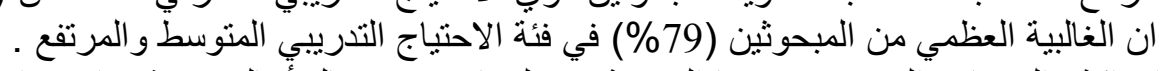

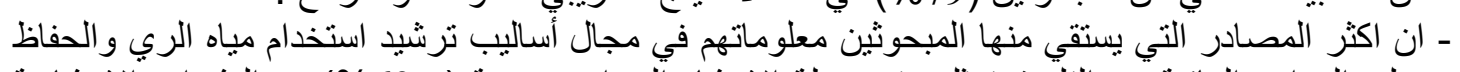

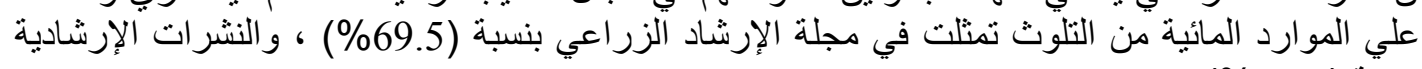

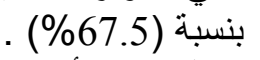

- حو الي ثناثة أرباع المبحوثين (74.8\%) لم يتلقو ا تدريباً في مجال أساليب ترشيد استخدام مياه الري و الحفاظ

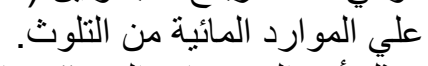

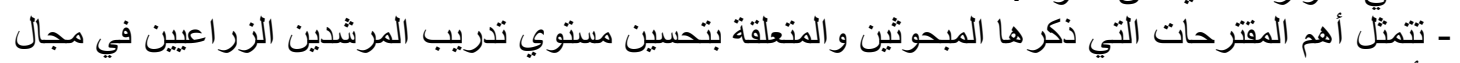

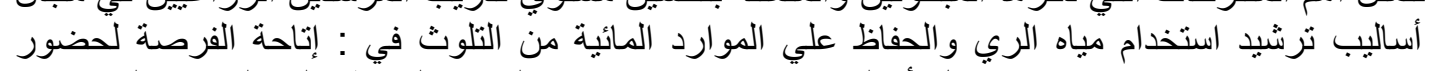

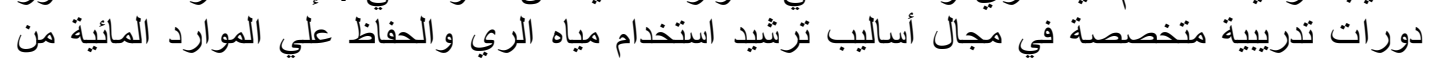

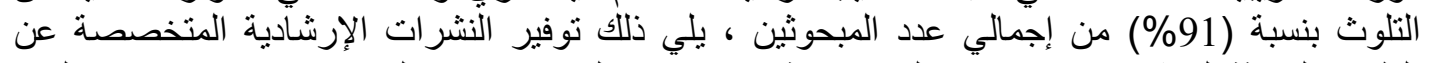

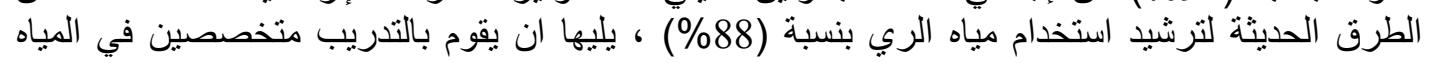

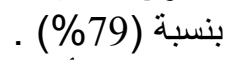

ـ اتضح ان أهم الموضوعات التئي يرغب المبحوثين الحصول علي دورات تدريبية فيها والمتعلقة بمجال

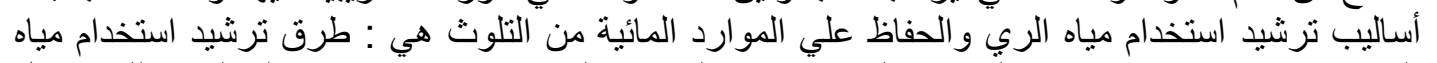

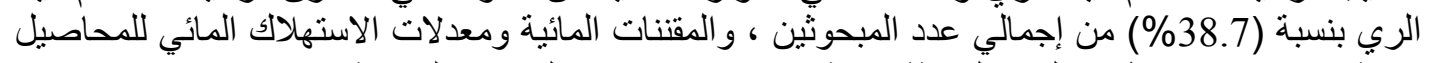

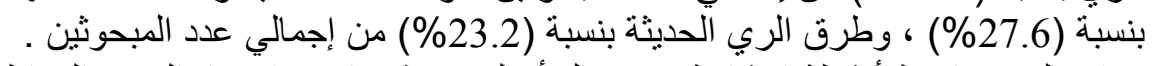

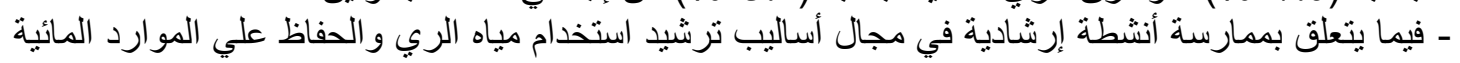

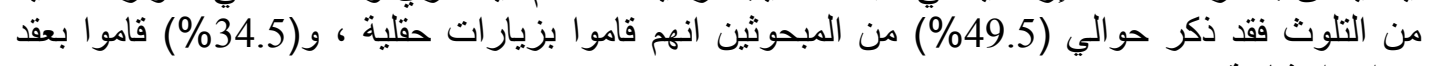
ندو ات إرشادية . تونة

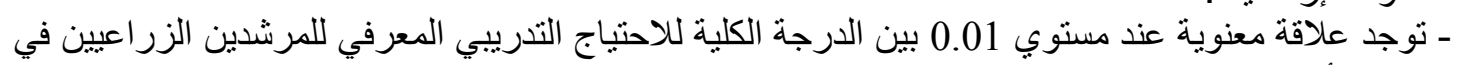

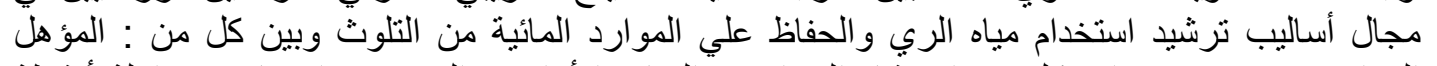

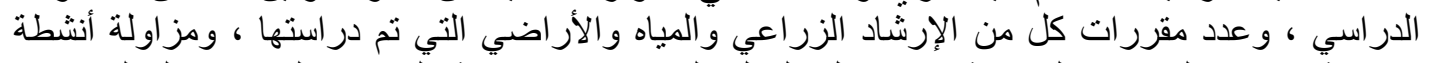

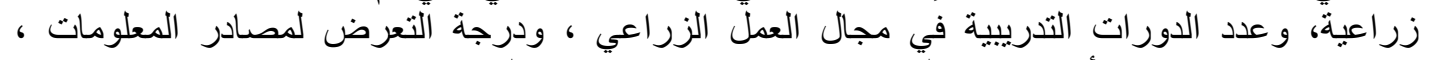

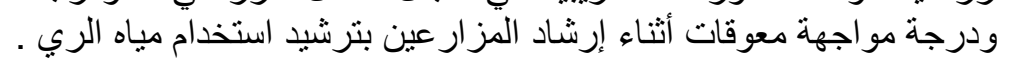




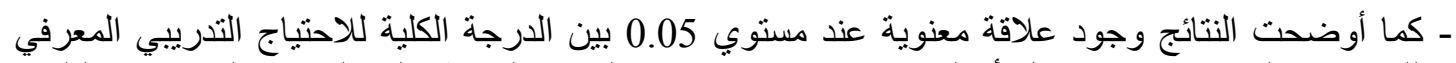

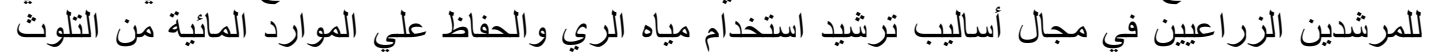

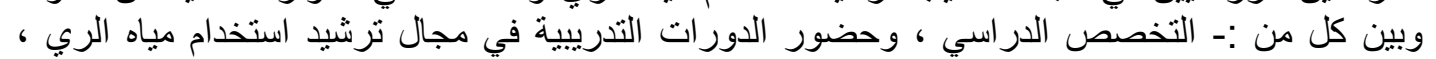

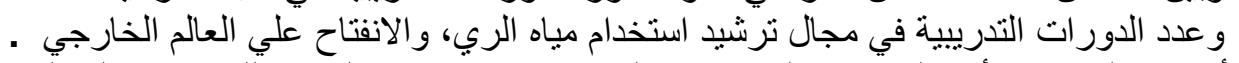

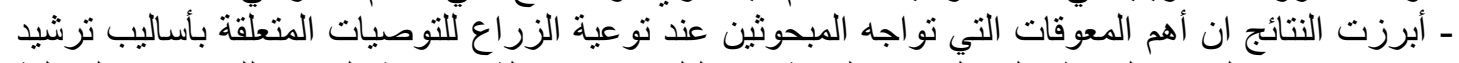

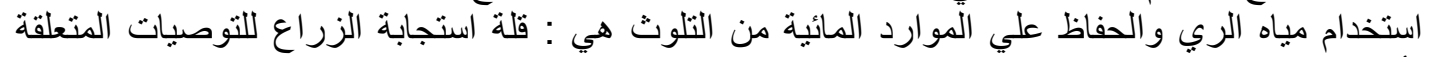

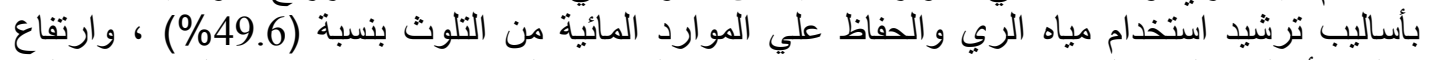

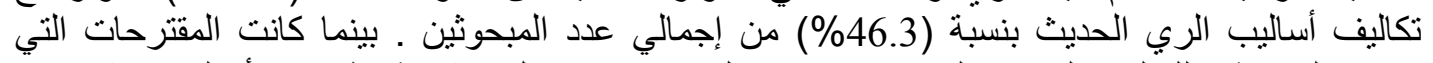

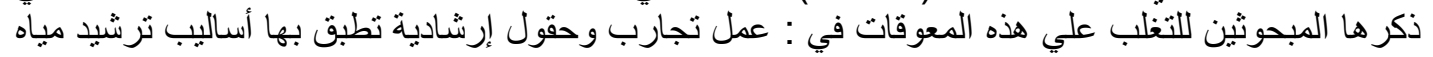

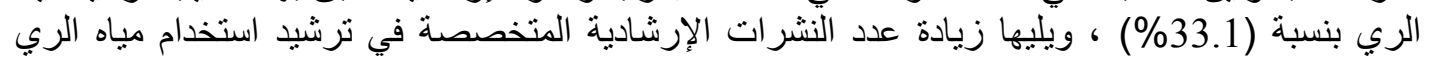

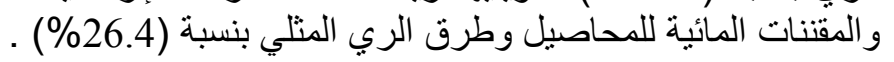

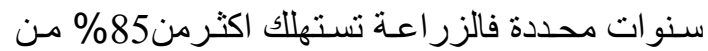

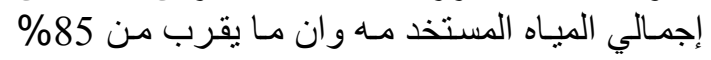

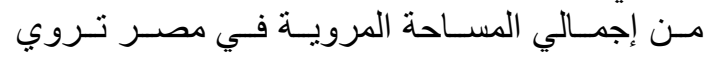

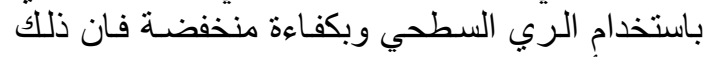

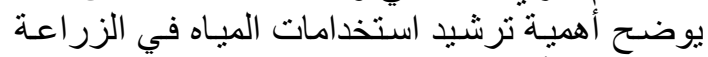

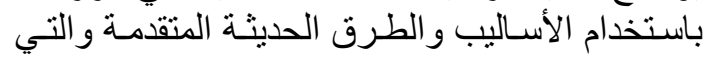

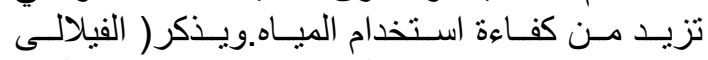

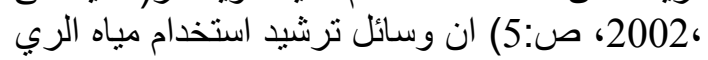

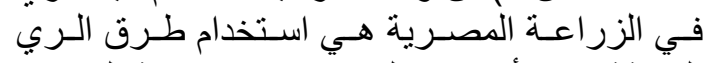

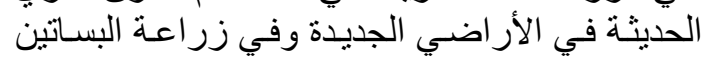

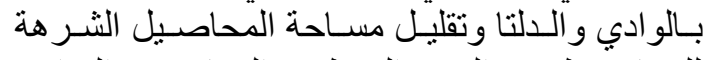

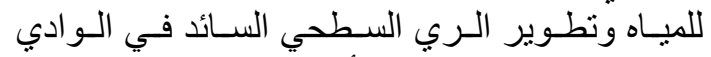

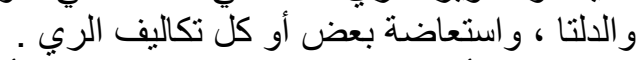

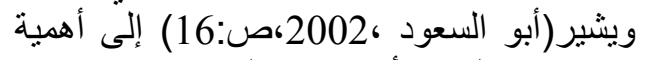

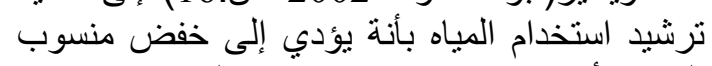

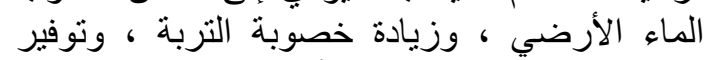

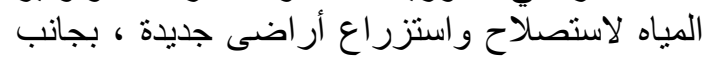

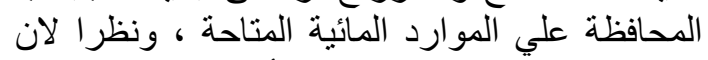

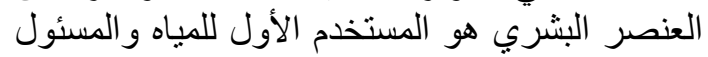

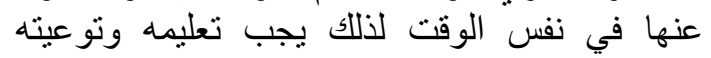
وتغيير اتتجاهاته فيما يتعلق باستخدام الموارد المائية

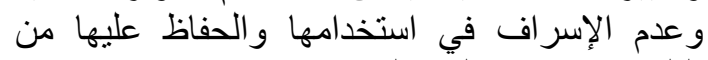

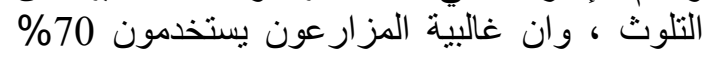

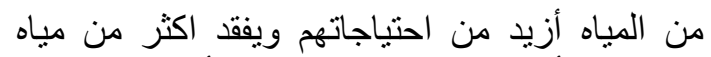

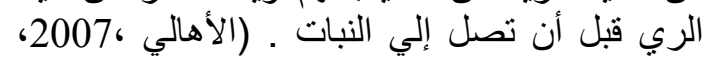
أن تغيير السلوك الإنساني يتوقف علي المعرفة فان كمية المعلومات المنوفرة الإنساني عن نرشيد مئ مياه الري الري

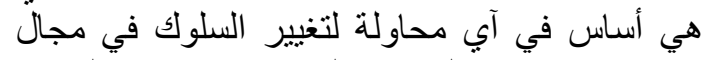

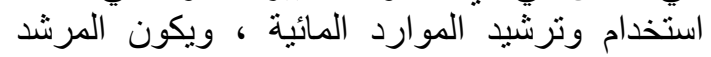

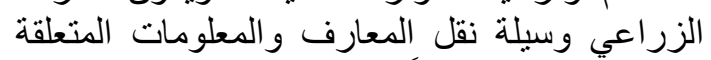

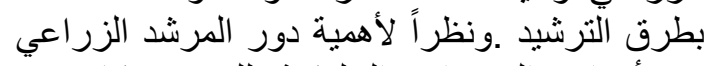

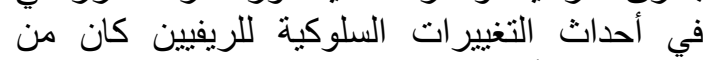

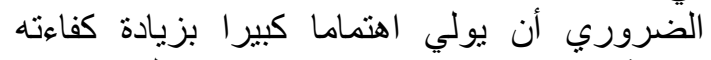

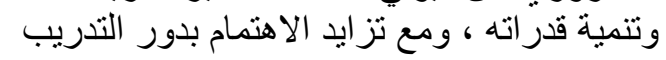

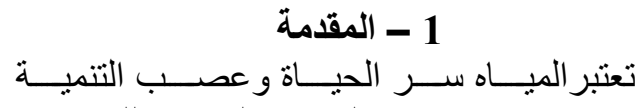

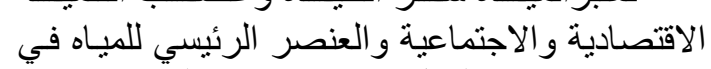

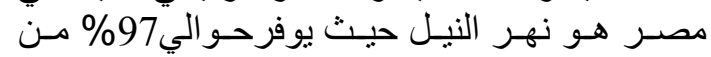

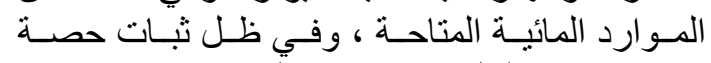

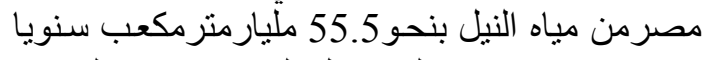

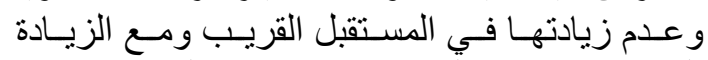

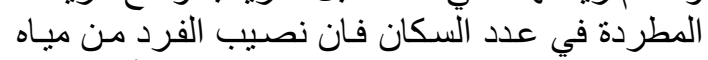

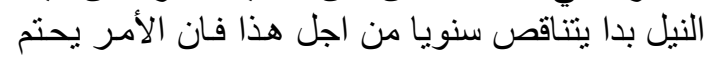

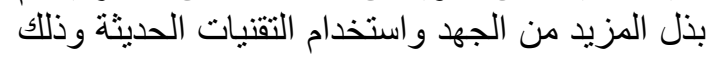

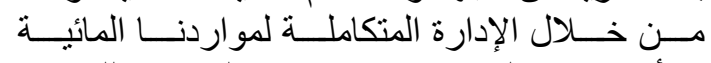

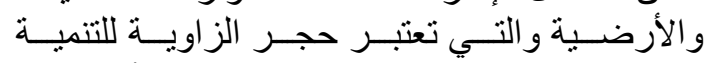

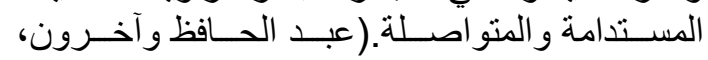

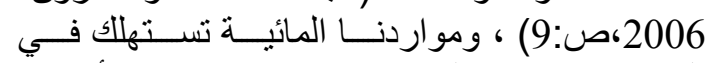

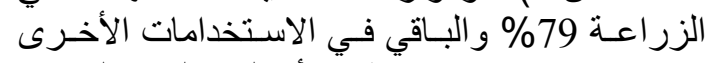

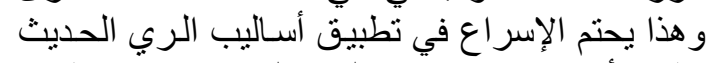

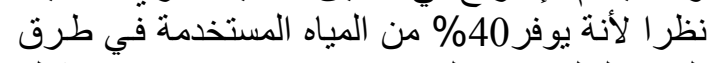

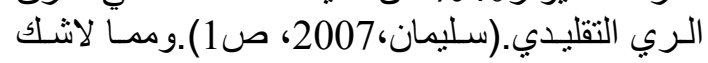

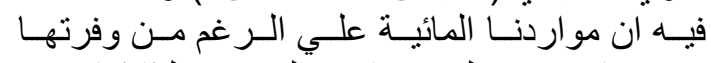

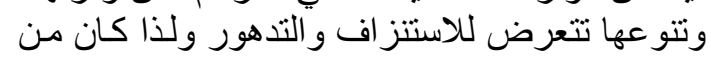

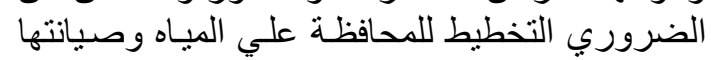

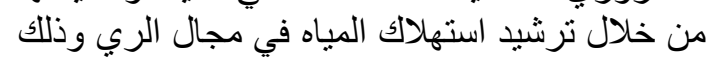

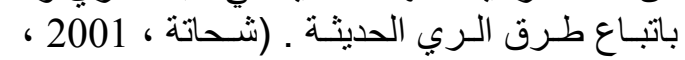

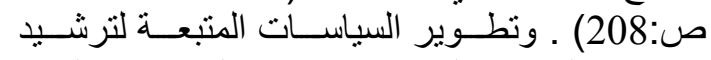

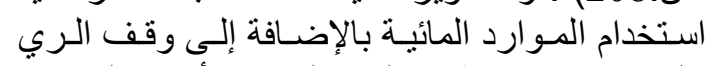
بالغمر واستخدام طرق الري الرئة الحديث.(أخبار البيئة ،

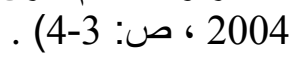

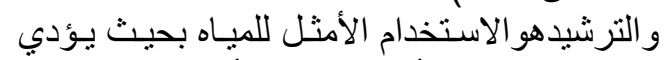

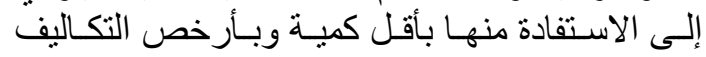

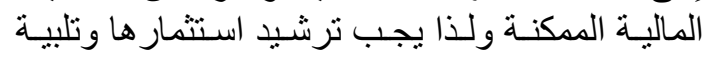

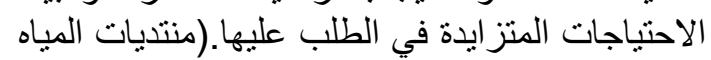

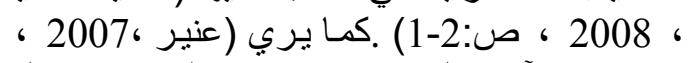

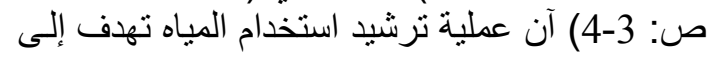

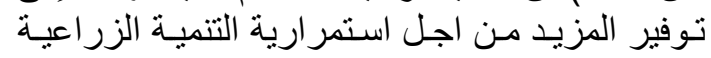

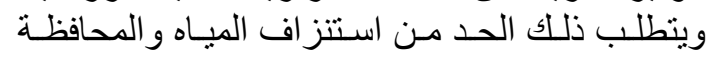

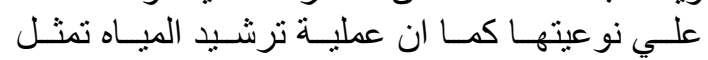

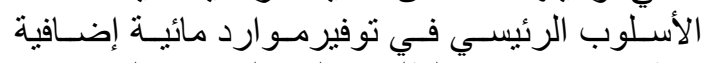

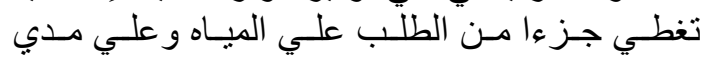


بينت در اسـة (زيـدان ،2000، ص:125)ان احتيـاج المرشدين للمعلومـات المتعلقة بأسـاليب استخدام مياه

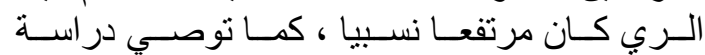

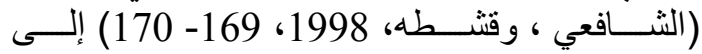

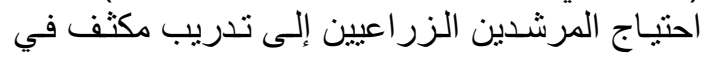

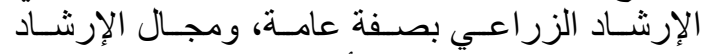

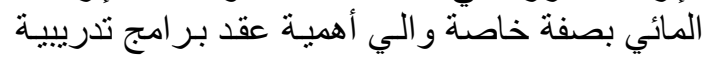
للمرشدين الزر اعيين في مجال الإرشاد المـائي تركز تلائي

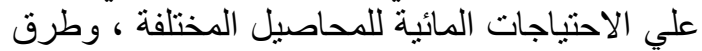
الري الحديث التي توفر استهلاك مياه الري.

\section{2- 2- 20 - 2 المشكلة البحثية}

تمثل محدودية الكمية المتاحة من الموارد المائية

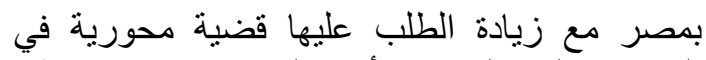
التنمية ، ولكن القضية الأكثر إلحاحا هي كيفية تنظية التئية

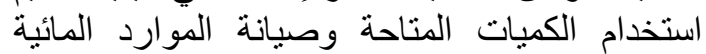

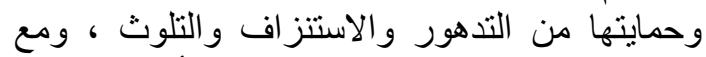

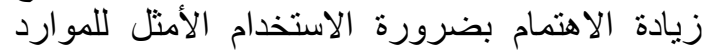

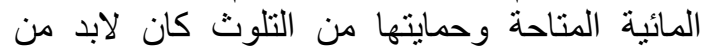

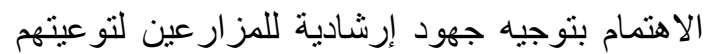

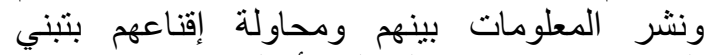
التوصيات الإرشادية المتعلقة بأساليب ترشيد استخدام

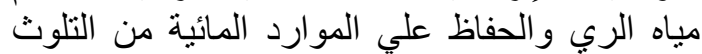

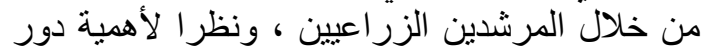

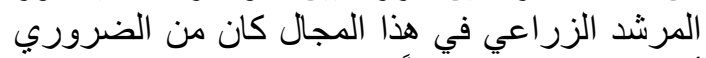

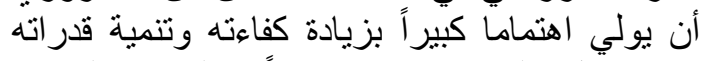

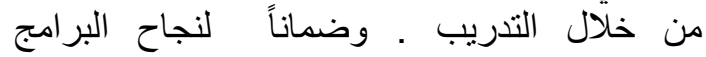
التدرييية في مد المرشدين الزراعيين بالمعان المعارف

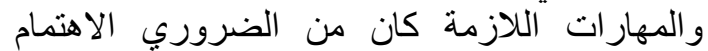
بتقدير احتباجاتهم التدريبية في هذان المجال.

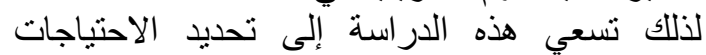

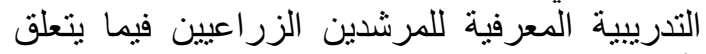

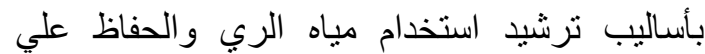
الموارد المائية من التلوثيد ، ودئم ودرأسة العلاقة بين

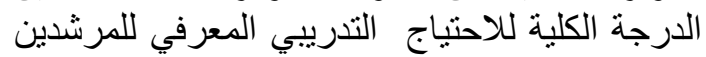

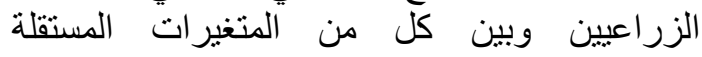

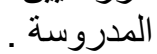

\section{3- أهداف البحث}

في ضؤ ما سبق واتساقا مع مشكلة البحث صيغت البه الأَّاف التالية :

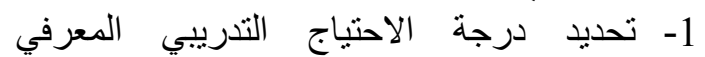

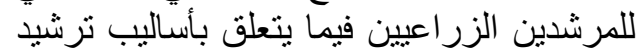

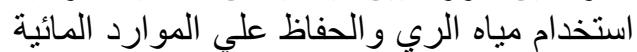
من التلوث في محافظة الدقهلية.
في تنمية المرشدين الزراعيين ومدهم بالمعارف

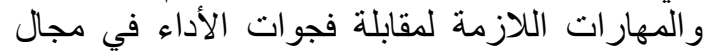

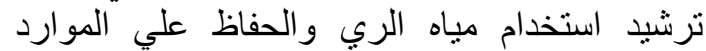

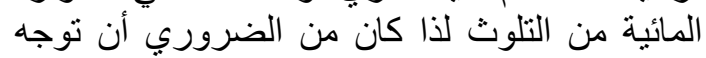
برامج تدريبية للمرشدين الزراعين لاعيين نحو الوفي الوفاء باحتباجاتهم .

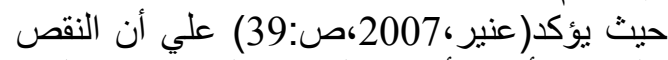
في التدريب أحد الأسباب الرئيسية لسوء إدارة إني الري الفي علي مستوي المز ارعين حتى تبقي مهارتهم في إدارة النيا

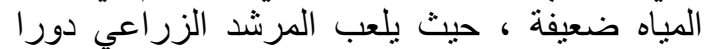

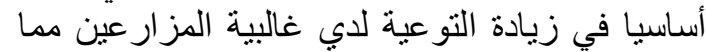

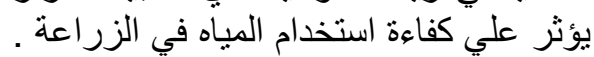

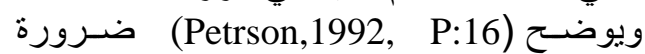
تقدير الاحتياجات التدريبية لتصميم البرامج الموجهة

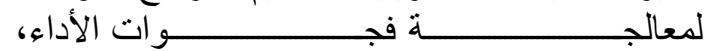

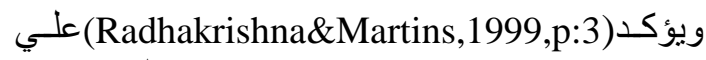

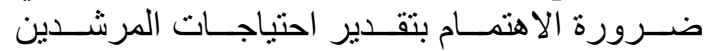
الزراعيين لإمكان بناء البرامج الإرشادية الفعالة التي التي

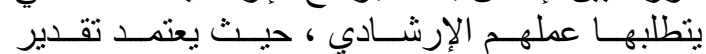

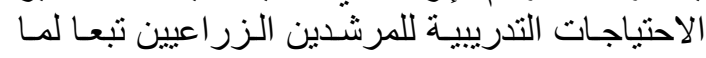
يوضحه (Boydell,1990,p:4 )علي تحديد القصور

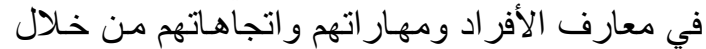

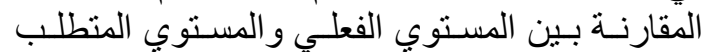
للأداء الفعال و القيام بدر اسـة وتحليل الفيل الفجوة القائمسة ،

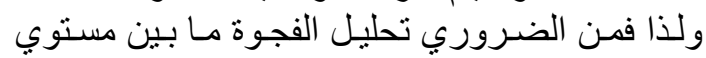

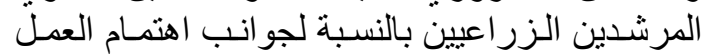

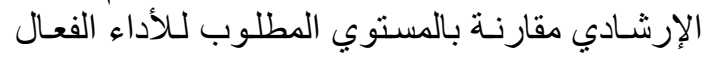

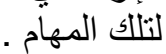

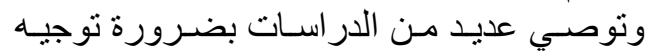
جهود إرشادية في مجال أساليب ترشيد استخدام ميناه

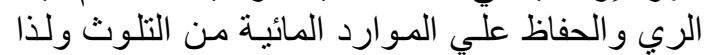

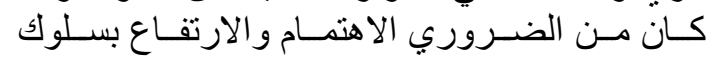

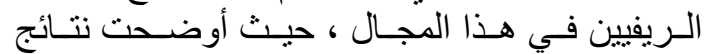

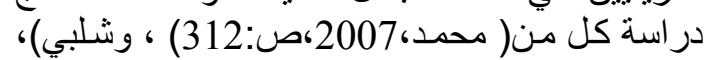

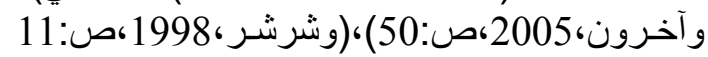

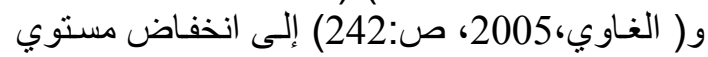

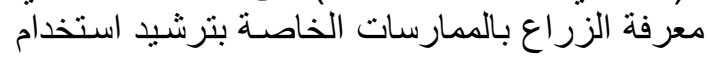

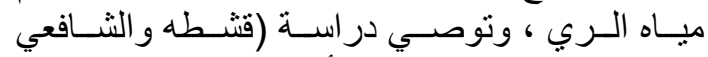

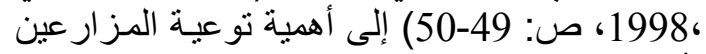

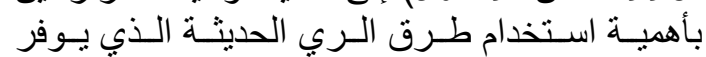

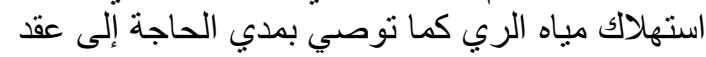

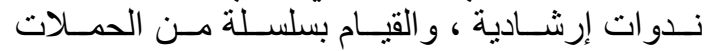

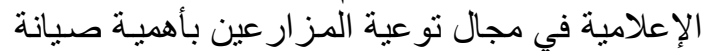

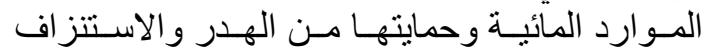

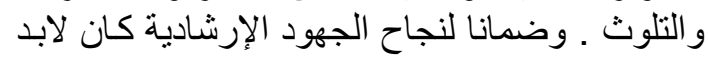

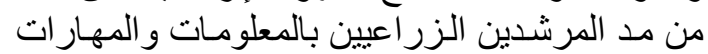

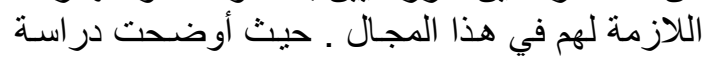

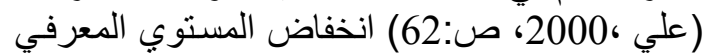
للمرشدين الزر اعيين في مجال ترشيد استخدام ميادياه الري و الحفاظ علي الموارد المائية من التلوث فئ ، كمـا 
المائية من التلوث والحلول المقترحة للتغلب عليها

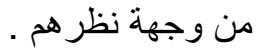
الفرض البحثي:

ولتحقيق الَّدف السادس من البحث تم صباغة

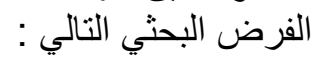

توجد علاقة معنوية بين الدين الدرجة الكلية للاحتياج التدريبي المعرفي للمرشدين الزراعينين في في مجال

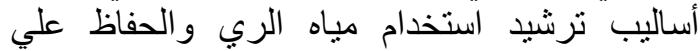
الموارد المائية من التلوث وبيد التين كل من المتغيرات المستقلة المدروسة.

\section{4 - الطريقة البحثية}

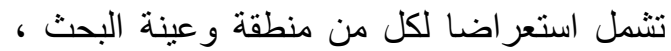

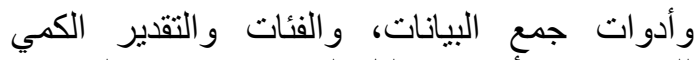
للاتغير ات، وأدوات تحليل البيانات وات وعرض الفيات والنتائج.

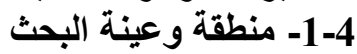

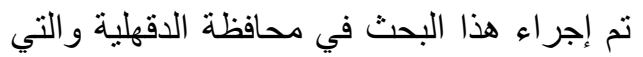
تعد اكبر محافظات جمهورية مصر الجرات العربية في زراعة محصول الأرز حيث بلغت مساحة الأرز

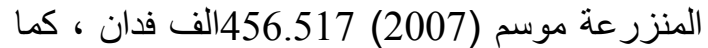
أنها من اكبر المحافظات استهلاكا لمياه الري (إدارة الإرشاد الزراعي بمحافظة الدقهلية ، 2007: بيانات الثرات

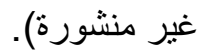

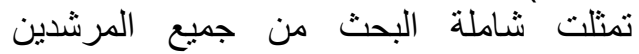
الزراعيين بمحافظ الدقهلية والبالغ عددهم (429) مرشدا زراعيا وقد اختيرت عينة البحث بالطريقة

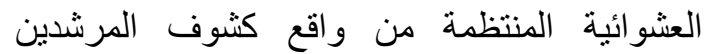
الزراعيين بمر اكز محافظة الدقهلية وقد تم تحديد حجم العينة من المبحوثين بمعلومية حجم الثناملة

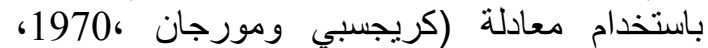
صائ607-610) ، وقد بلغ حجم العينة المطلوبة بعد

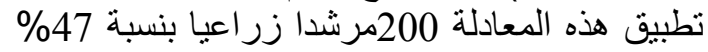

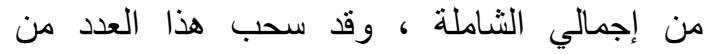

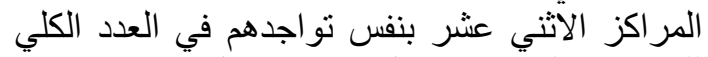

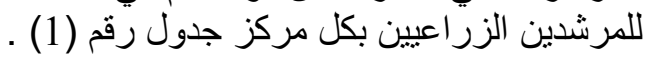

جدول رقم (1) : توزيع عينة الدراسـة من المرشدين الزراعيين

\begin{tabular}{|c|c|c|c|}
\hline عدد أفر اد العيناً & عدد المرشدين & المركز & 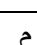 \\
\hline 12 & 26 & طلذا & 1 \\
\hline 10 & 22 & تمي ألا مديد & 2 \\
\hline 13 & 27 & ميتّ سوبد & 3 \\
\hline 13 & 28 & دكرنس & 4 \\
\hline 16 & 34 & شربين & 5 \\
\hline 12 & 26 & منية النصر & 6 \\
\hline 25 & 54 & المنصورة & 7 \\
\hline 19 & 41 & ميت غمر & 8 \\
\hline 27 & 58 & السنبلاوين & 9 \\
\hline 21 & 44 & أجا & 10 \\
\hline 20 & 43 & بلقاس & 11 \\
\hline 12 & 26 & المنزله & 12 \\
\hline 200 & 429 & المجموع & \\
\hline
\end{tabular}

2- التعرف علي مصادر معلومات المرشدين الزر اعيين في مجال أساليب ترشيد استخدام مياه

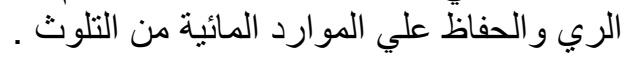

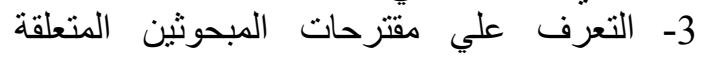
بتحسين مستوي تدريب المرشدين الزراعيين

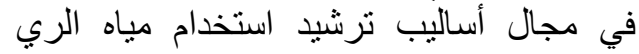

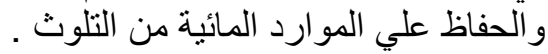

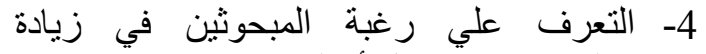
معلوماتهم في مجال أساليب ترشيد استخدام مياه

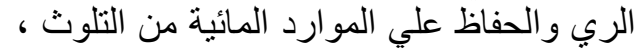

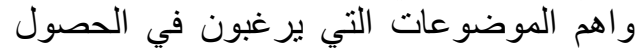
علي دورات تدرييية لزيادة معلوماتهم عنها في التي الي

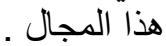
5- التعرف علي أهم الأنشطة الإرشادية المبذولة

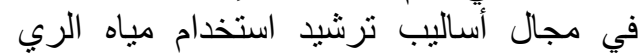

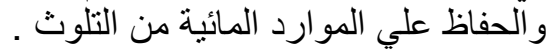
6- دراسة العلاقة بين الدراجة الدائة الكلية للاحتياج

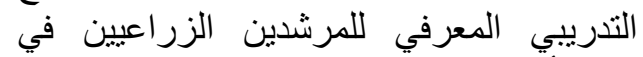

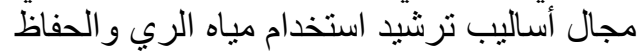

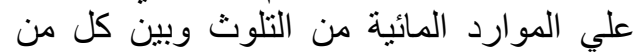

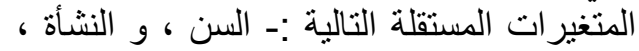

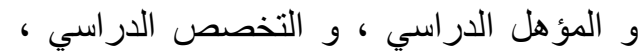

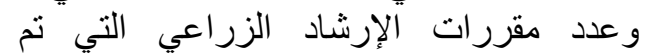
در استها ، و عدد مقررات الأر اضي و والمياه التي التي

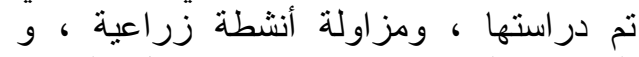

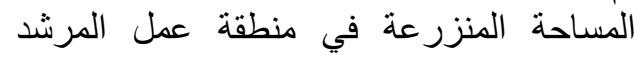

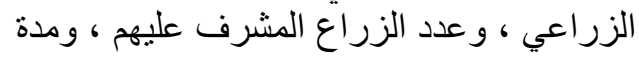

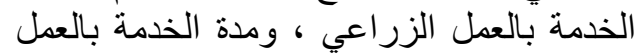

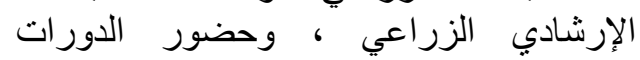

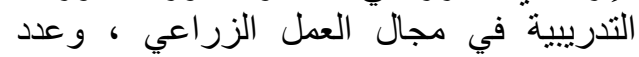
الدورات التدرييية في مجال العمل الزيج الزراعي ، وحضور الدورات التنديبية في مجال ترشيدال التربيد

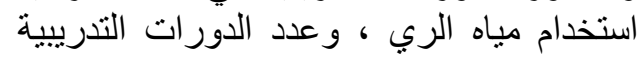
فى مجال ترشيد استخدام مياه الري الري ، وحضور

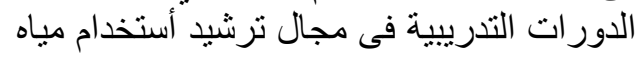

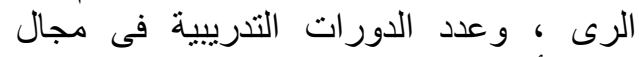

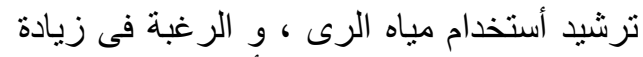

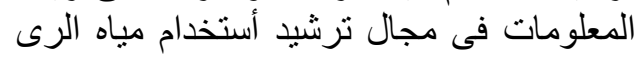

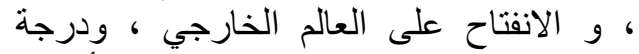
التعرض لمصادر المعلومات ، و و مزاوله أنشطة الرئة

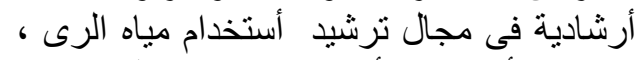
وعدد الأنشطة الأرشادية في في مجال ترشيد الريداه

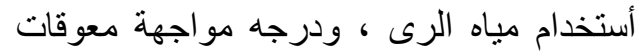
أثناء أرشاد المزارعين بترشيد استخدام مياه

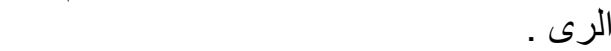
7- التعرف علي المعوقات التي تواجه المرشدين

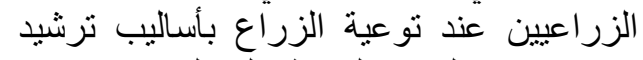
استخدام مياه الري و الحفاظ علي المو ارد بالئ 
- المساحة الزراعية في منطقة عمل المرشد :

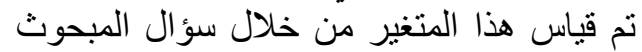
عن المساحة الزر اعية في منطقة عملة بالفئ بالفدان.

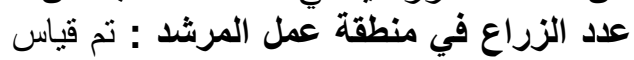

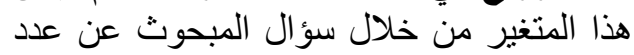
الزراع في منطقة عملة. مدة الخدمة بالعمل الزراعي : تم حسابها بعدد

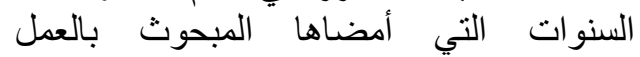

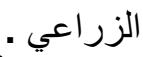

مدة الخدمة في العمل الإرشادي الزراعي : نم

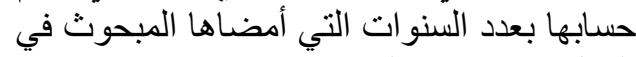

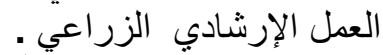
حضور الإورات التدريبية في مجال الزئية العمل الزراعي : اشتملت علي فئتين : ( حضر في لم لم

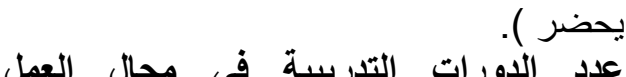

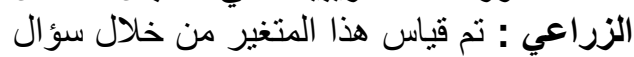

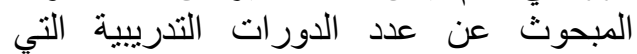

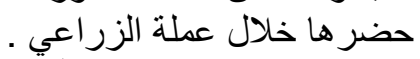
حضور الدورات التدريبية في مجال تربئ ترشيد

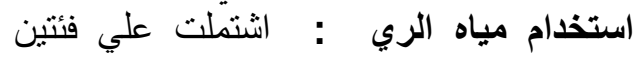

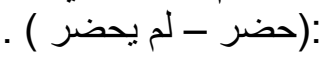
عدد الدورات التدريبية في مجال ترشيد استخدام مياه الري : تم قياس هذا فئال المتغير من

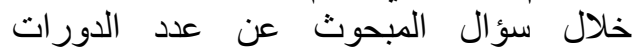
التدريبية التي حضرال هال في مجال ترشيد استخدي عندام

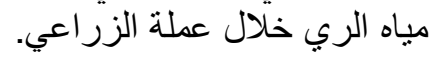

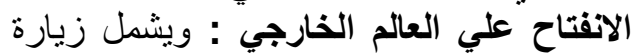

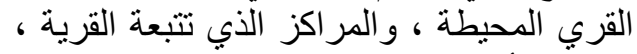

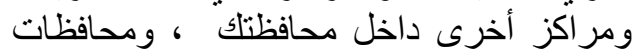

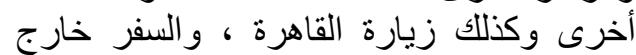

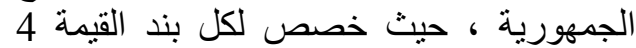

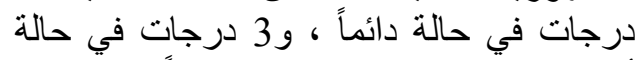

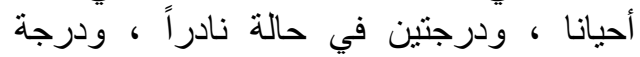

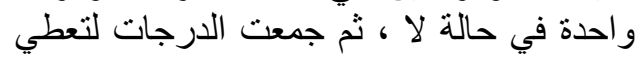

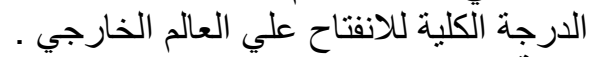

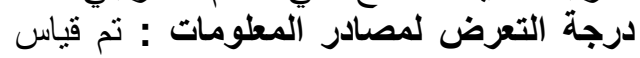

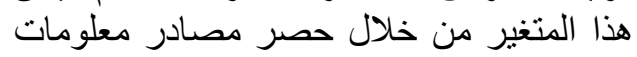
المبحوثين المتعلقة بأساليب ترشيد استخدام مياه

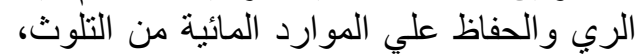

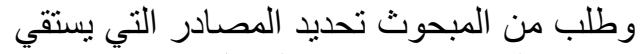

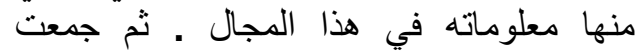
الدرجات لتعطي الدرجة الكلية لعدد مصادر

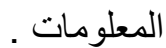

2-4 - جمع البيانات

تـم جمـع البيانـات الميدانيـة باسـتخدام اســـــارة

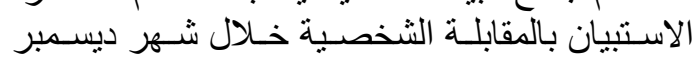

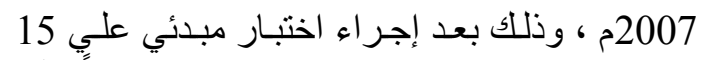

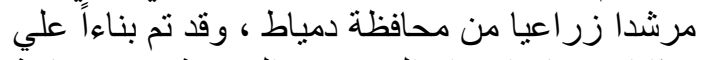

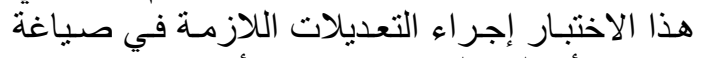

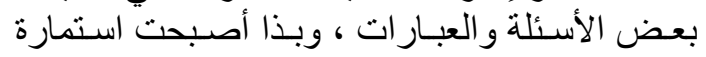

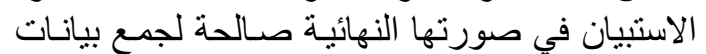

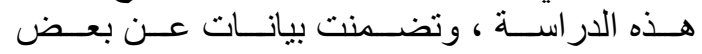

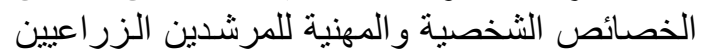

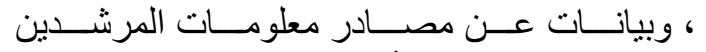

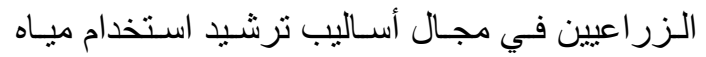

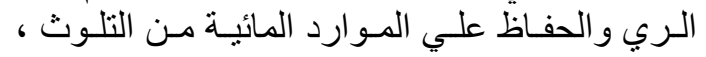

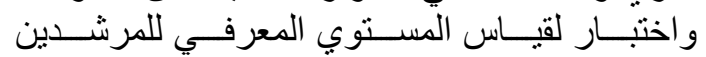

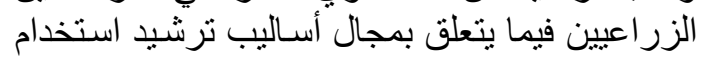

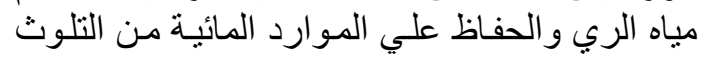

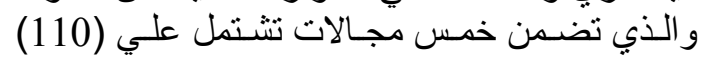

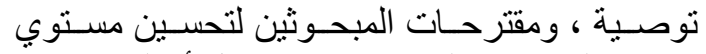
تدريب المرشدين الزر اعيين في مجال أساليب ترشيد

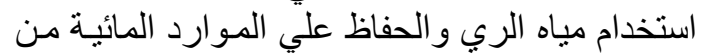
3-4 - الفئات والتقاير الكمي للمتفيرات

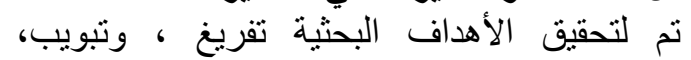

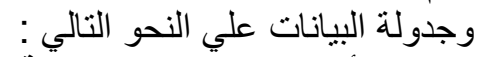

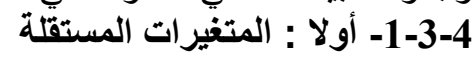
- - السن: نم تقديرة من خلاول استخدام الأرقام الخام

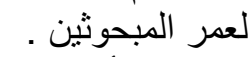

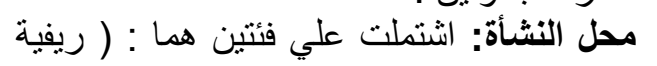

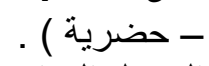
المؤهل الدراسي : ويقصد به آخر درجة علمبة

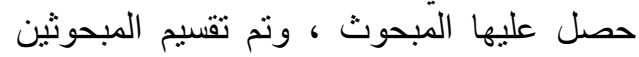

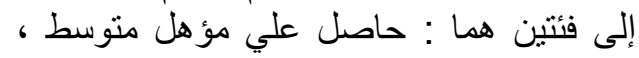

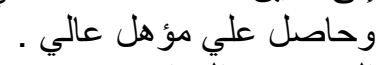

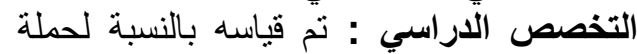

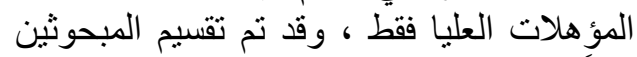

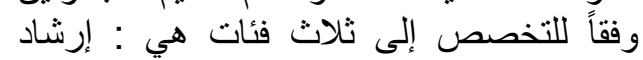
زراعي ، وشعبة عامة ، وتخصصات زلفئ زراعية

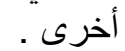
عدد مقررات الإرشاد الزراعي التي تم دراستها

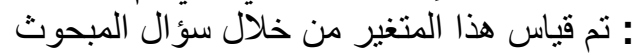

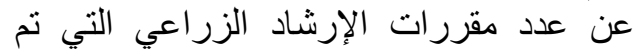
در استها خلال مر احل تعليمة.

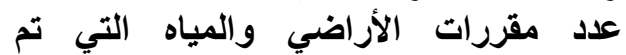

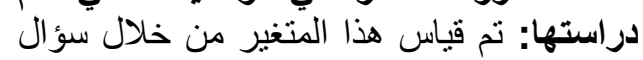

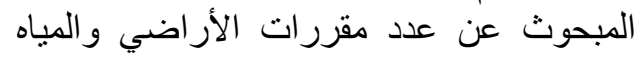

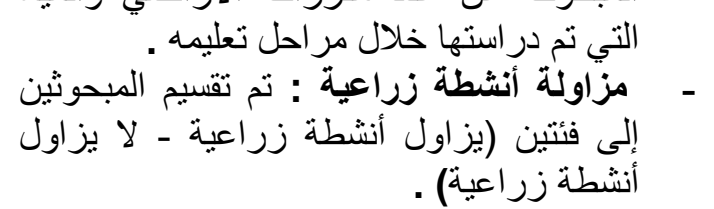


الزراعيين في مجالات ترشيد استخدام مياه الري وذللك علي النحو التالي :

1-1-5 آلتقتيات الحديثة لاستخدام مياه الري :

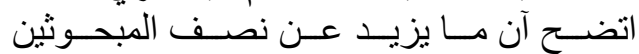

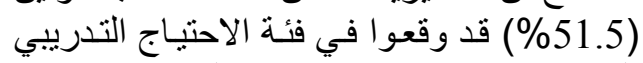

المتوسط ، وان (28.5\%) من المبحوثين وقعوا

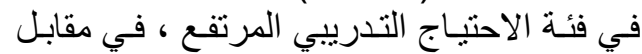

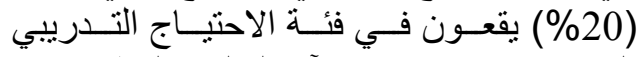

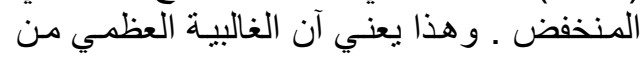

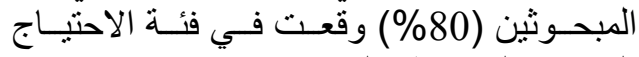

$$
\text { التدريبي المتوسط و المرتفع . }
$$

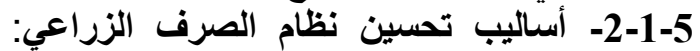

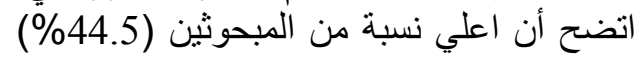

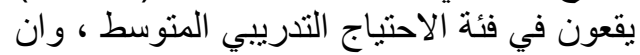

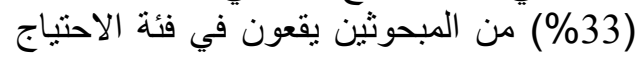

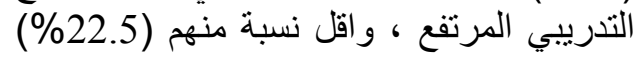

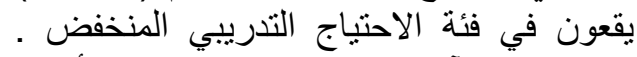

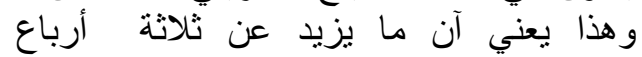
المبحوثين (77.5\%) وقعت في فئئة الاحتياج التدريبي المتوسط و المرتفع .

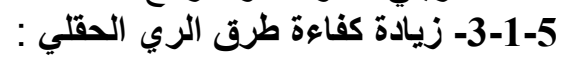

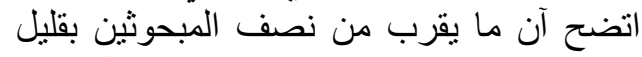
(46.5\%) يقعون في فئة الاحتياج التدريبي

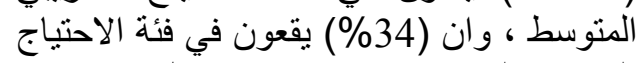
التدريبي المرتفع ، في حين كانت أقل نسبة منهم الأني

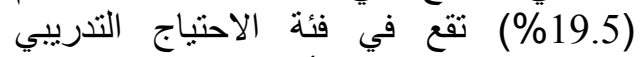

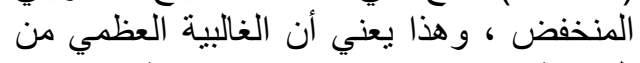
المبحوثين (80.5\%) وقيط المت في فئة الاحنياج

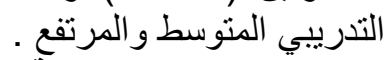

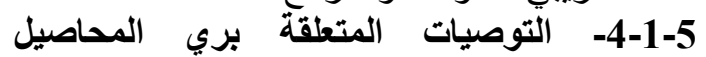

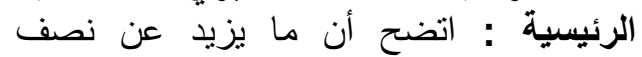
المبحوثين (55.5\%) يقعون في فئة الاحتياج

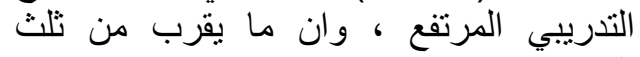
المبحوثين (29.5\%) تقع في فئة الأنة الاحتياج التدريبي المنخفض المن . وهذا يعني أن الغالبية

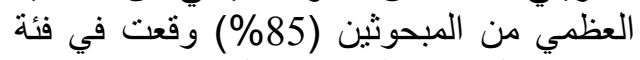

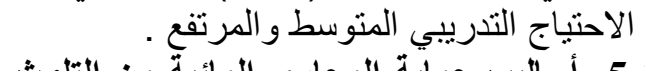

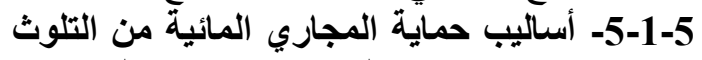

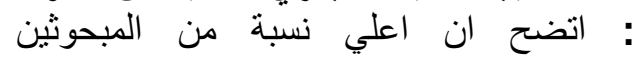
(60.5\%) قد وقعوا في فئة الاحتياج التدريبي التئي

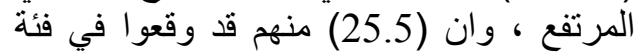

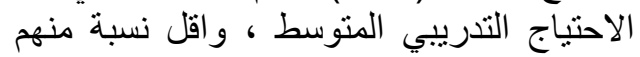

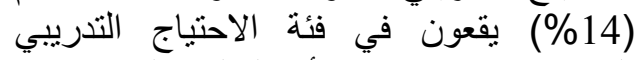

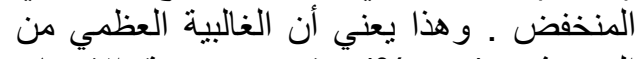

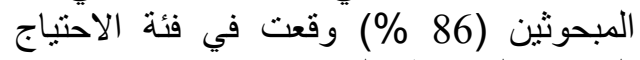
التدريبي المتوسط و المرتفع .
- مزاولة أنشطة إرشادية لتوعية المزارعين

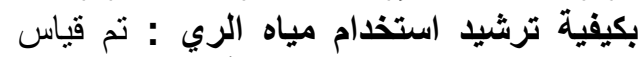
هذا المتغير من خلال حصر الأنشطة الإرشادية

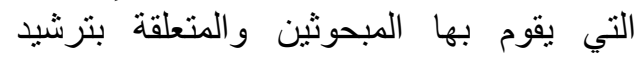
استخدام مياه الري و الحفاظ علي المو المن ارد المائية

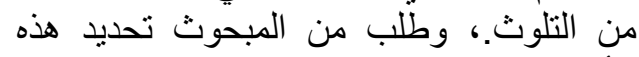

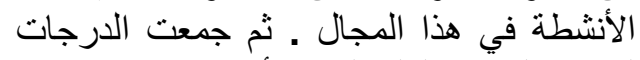

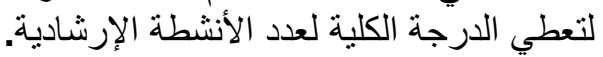

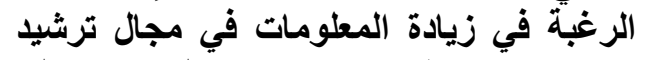

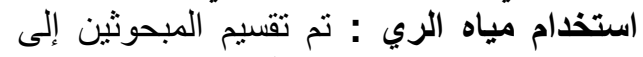

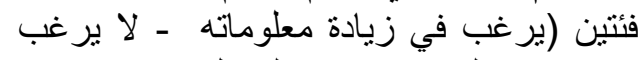

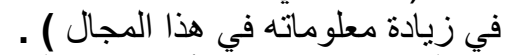

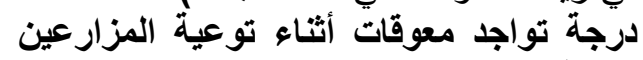

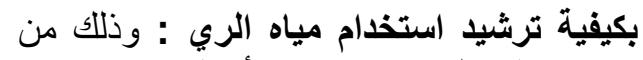

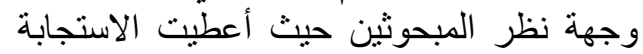

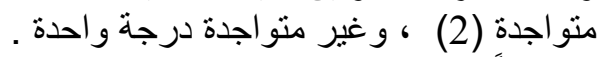
2-3-4 - ثنانياً : المتغير التابع

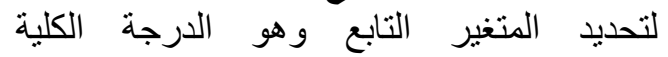

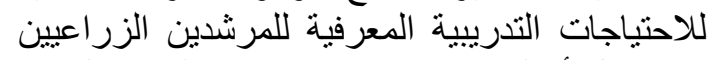

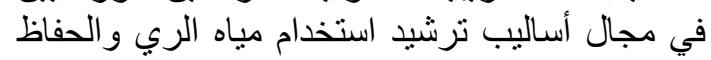

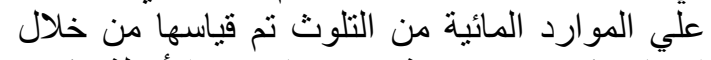

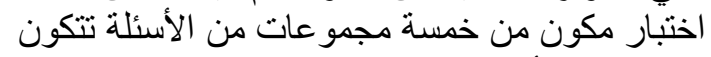

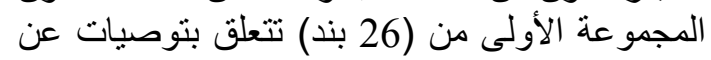

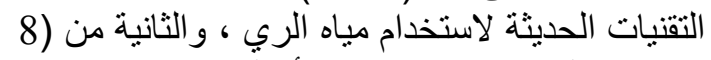

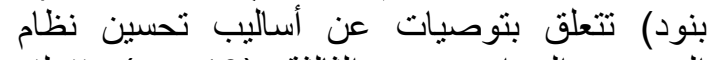

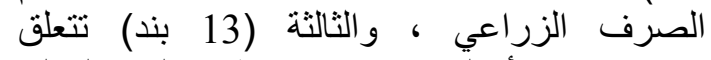

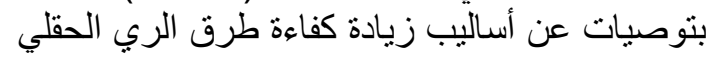

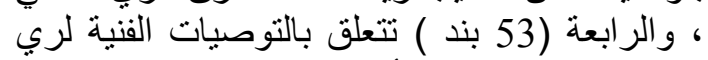

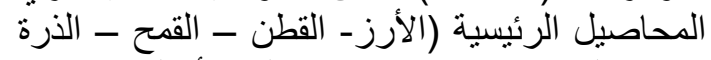

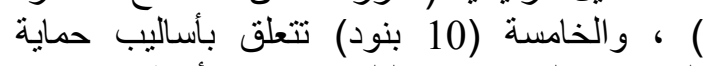

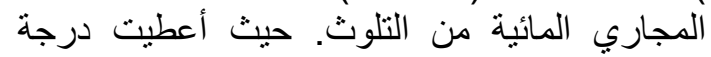

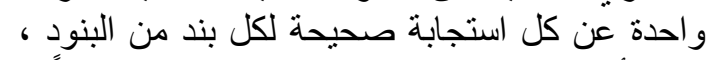

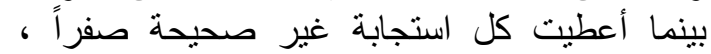
وبذللك بلغ الحد الأقصى للمستوي المعرفير (110)

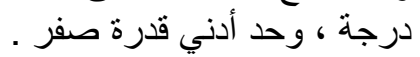
4- 4 - تحليل البيانات استخدم في تحليل البيات البيانات العرض الجدولي

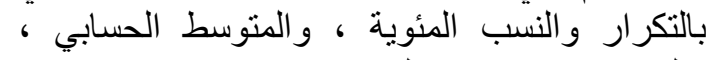

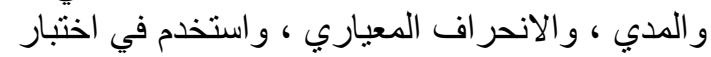

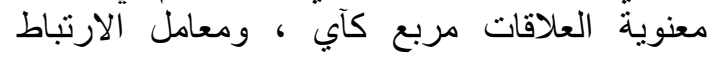
البسيط لبيرسون لتحديد العلاقة بين العين المتغير التئن التابع وبين كل من المتغير ات المستقلة المدروسة لئل

\section{5- النتائج ومناقشتها}

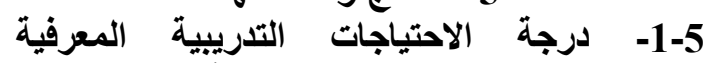

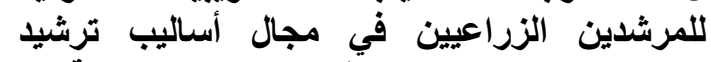
استخدام مياه الري والحفاظٍ علي الموارد المائية من فئن التلوث .

تثير النتائج الواردة بجدول رقم (2) إلى ارتفاع

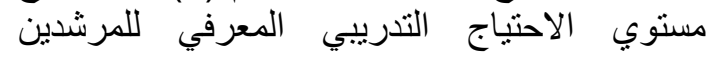


وخاصة في طرق ترشيد استخدام مياه الري ، ولري

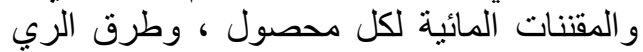
الحديث ، والتي اتضح وجود رغبة فية قوية لدي لري

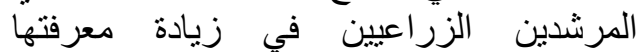
و الحصول علي دورات ندريبية فيها.
6-1-5- الدرجة الكلية للاحتياج التدريبي المعرفي للمرشدين الزراعيين في مجال أساليب ترشيد الميدي استخدام مياه الري واعين في الحفاظ علي المئي الموارد

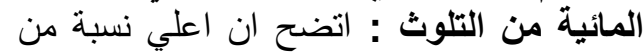

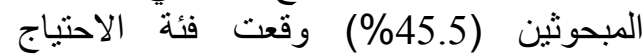
التدريبي المتوسط ، وان (33.5\%) منهم يقعون

جدول رقم (2) : توزيع المبحوثين وفقاً لمستويات احتياجاتهم التدريبية المعرفية في كل مجال من مجالات

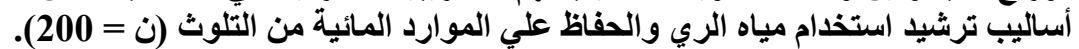

\begin{tabular}{|c|c|c|c|}
\hline$\%$ & عدد & فئات مستوي الاحتياج & المجالات \\
\hline 20 & 40 & احتياج منخفض (0 - 4 درجات ) & التقنيات الحديثة لاستخدام مياه الري \\
\hline 51.5 & 103 & احتياج منوسط (5 - 9 درجات ) & \\
\hline 28.5 & 57 & احتياج مرتفع (10 درجات فأكثر) & \\
\hline 22.5 & 45 & احتياج منخفض ( 0 - 1 درجة ) & أساليب تحسين نظام الصرف الزر اعي \\
\hline 44.5 & 89 & احتياج متوسط ( 2- 3 درجات ) & \\
\hline 33 & 66 & احتياج مرتفع (4 درجات فأكثر ) & \\
\hline 19.5 & 39 & احتياج منخفض ( 0 - 3 درجات) & زيادة كفاءة طرق الري الحقلي \\
\hline 46.5 & 93 & احتباج منو سط ( 4 - 7درجات ) & \\
\hline 34 & 68 & احتياج مرتفع (8 درجات فأكثر ) & \\
\hline 15 & 30 & احتياج منخفض (14- 26 درجة ) & التوصيات المتعلقة بري المحاصيل الرئيسية \\
\hline 29.5 & 59 & احتياج منوسط (27- 39درجة ) & \\
\hline 55.5 & 111 & احتياج مرتفع (40 درجة فأكثر ) & \\
\hline 14 & 28 & احتياج منخفض (1 - 3 درجة) & أساليب حماية المجاري المائية من التلوث \\
\hline 25.5 & 51 & احتياج متوسط (4 - 6 درجات) & \\
\hline 60.5 & 121 & احتباج مرتفع (7درجات فأكثر ) & \\
\hline 21 & 42 & احتياج منخفض (31- 50 درجة) & الدرجـة الكليـة للاحتيــاج التـــريبي المعرفـي \\
\hline 45.5 & 91 & احتباج متوسط (51 - 70 درجة) & للمرشدين الزراعيين في مجال أسـاليب ترشيد \\
\hline 33.5 & 67 & احتياج مرتفع (70درجة فأكثر ) & من التلوثد مياه الري و الحفّاظ علي الموارد المائية \\
\hline
\end{tabular}

2-5- مصادر معلومات المبحوثين في مجال أساليب

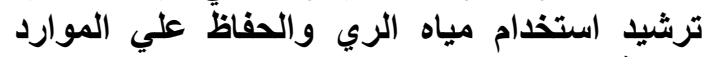

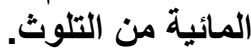

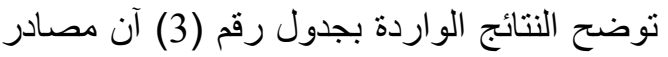

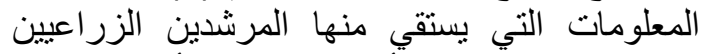
معلوماتهم في مجال أساليب ترشيد أستخدام مياه

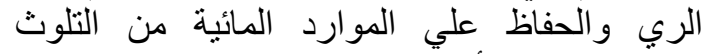

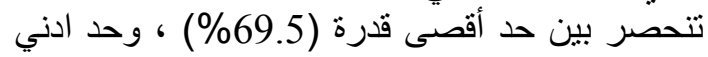

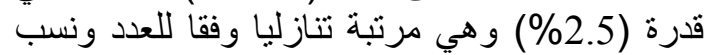

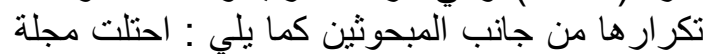

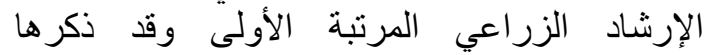

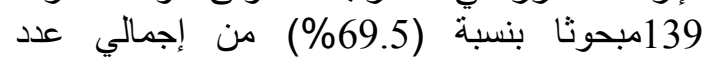
المبحوثين ، بليها في المرنبة الثنانية النشرات الإرشادية وقد أشار فين إليها 135مبحوثا بنسبة

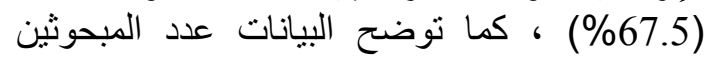

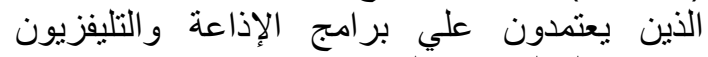

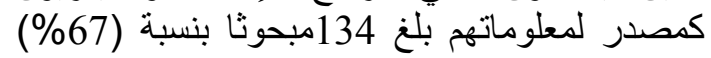
من إجمالي عدد المبحوثين ، يلي ذلائك الرؤساء في

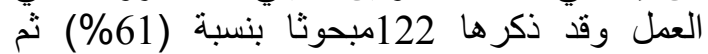

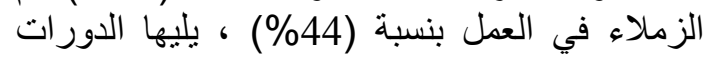

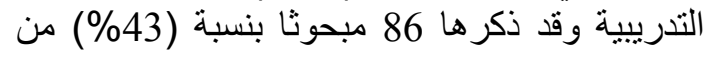

في فئة الاحتياج التدريبي المرتفع ، وان اقل نسبة منهم (21\%) يقعون في فئة الاحتياج التدريبي المنخفض ـ ـ وهذا بعني أن اكثر من فئ ثلاثة أرباع المبحوثين (79\%) وقالثعت في فئة

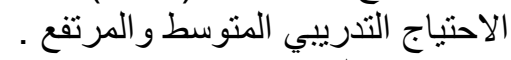
من هذه النتائج يتضح شندة الاحتياج التدريبي

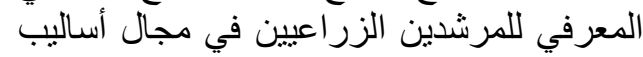

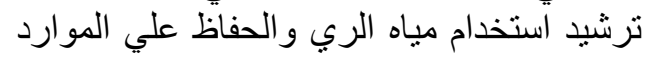

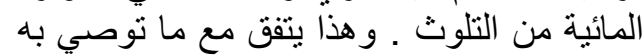

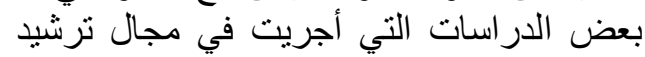
استخدام مياه الري والتي سبق التيق الإشارة إليها ،

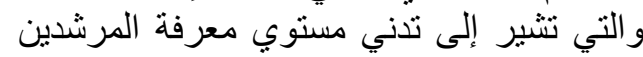

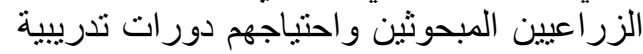

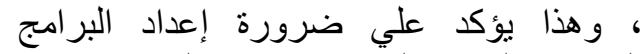

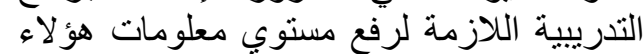

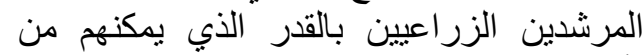

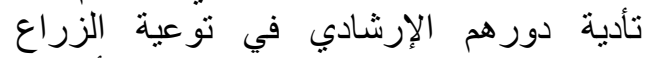

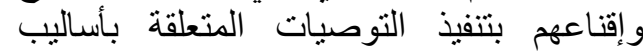
ترشيد استخدام مياه الري و والحفاظ علئ المني الموارد

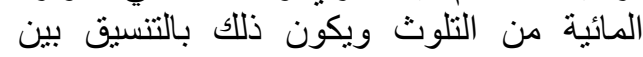
الجهات المسئولة عن الري ونهاز دلن الإرشاد 
النتائج بنفس الجدول إلى آن الغالبية العظمي من

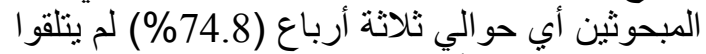

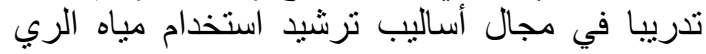

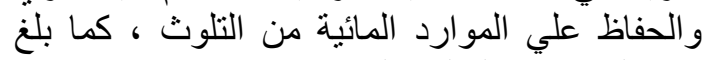

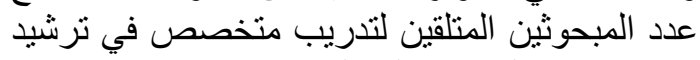

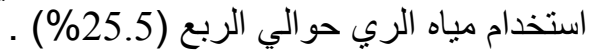
يلاحظ من النتائج السابقة ارتفاع نسبة المبحوثين غبر المنالقين لتدريب يتعلق بترشيد استخدام مياه

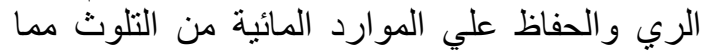

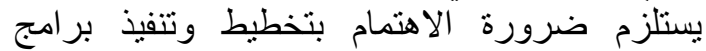

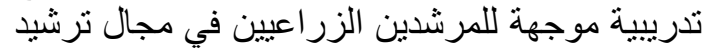

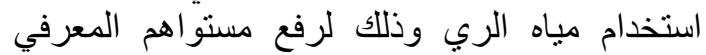

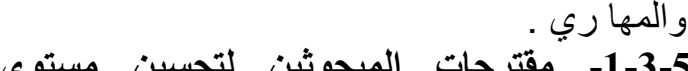
تدريب المرشدين الزراعيين في مجال أسلايب ترشيد استخدام مياه الري والحفاظ علي الموارد المائية من

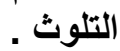

تنثير نتائج جدول رقم (5) آن أهم المقترحات التي

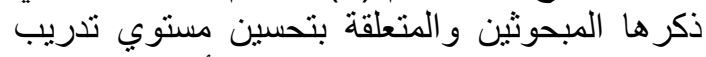

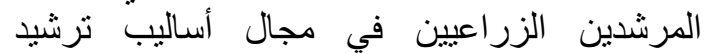
استخدام مياه الري والحفاظ علي الموارد المائية من من

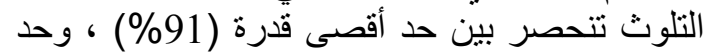

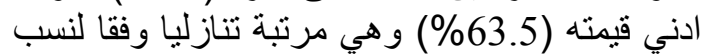

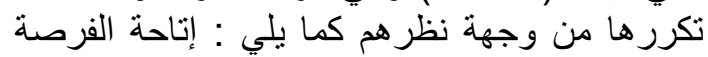

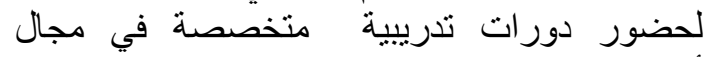

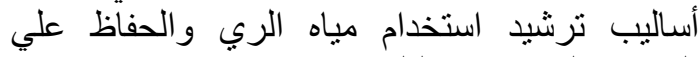

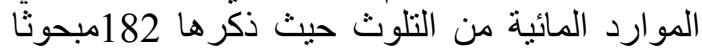

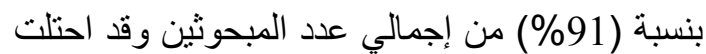
المرتبة الأولى ، يلي ذلك توفر النشرات الإرشادية

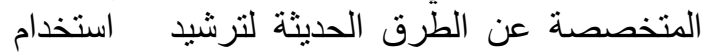
مياه الري والحفاظ علي المو ارد المائية من التلوث

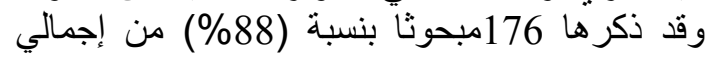

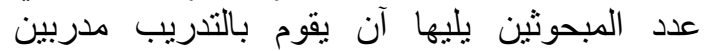

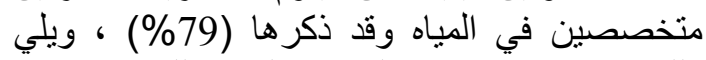

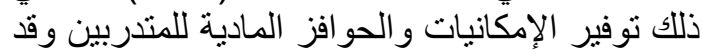
أشثار إليها 152مبحوثا بنسبة (76\%) ، بلئيها زيادة فرص التدريب العملي وتوفير وسائل الإيضاح العملي وقد ذكر ها 141مبحوثا بنسبة

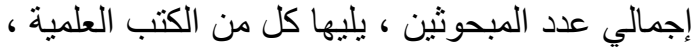

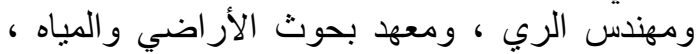
ومراكز البحوث المائية ، وروابط مستخدمي المباه

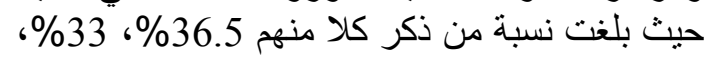

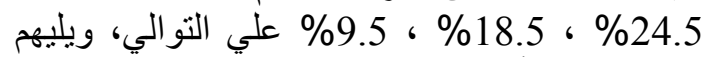
في المرتبة الأخيرة كليات الزراعة بنسبة 2.5\% من

جدول رقم (3) : توزيع المبحوثين وفقا لمصادر معلومـاتهم في

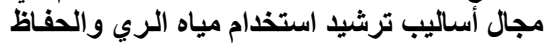
علي الموارد المائية من التلوث (ن = 200 2)

\begin{tabular}{|c|c|c|c|}
\hline$\%$ & عدد & المصادر & 5 \\
\hline 69.5 & 139 & مجلة الإرشاد الزراعى & -1 \\
\hline 67.5 & 135 & النشر ات الإرشادية " & -2 \\
\hline 67 & 134 & بر امج الإذاعة و التليفزيون & -3 \\
\hline 61 & 122 & الرؤساء في العمل & -4 \\
\hline 44 & 88 & الزملاء في العمل & -5 \\
\hline 43 & 86 & الدورات التدريبية & -6 \\
\hline 36.5 & 73 & الكتب العلمية & -7 \\
\hline 33 & 66 & مهندس الري & -8 \\
\hline 24.5 & 49 & معهد بحوث الأراضي & -9 \\
\hline 18.5 & 37 & و والمياه & -10 \\
\hline 9.5 & 19 & مركز البحوث المائية. & -11 \\
\hline 2.5 & 5 & كليات الزر اعتة. & -12 \\
\hline
\end{tabular}

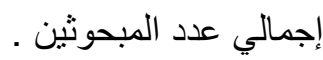

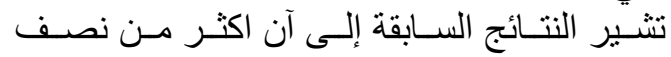

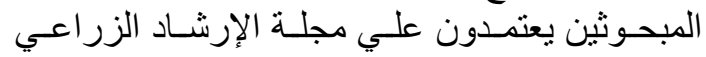

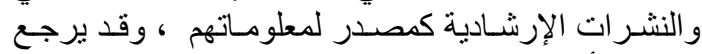

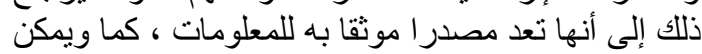
الرجوع إلى إليها في أب وقت من الأوقات.

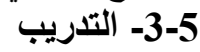

تم تقسيم المبحوثين تبعا لحصولهم لمه علي تدريب

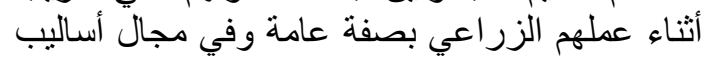

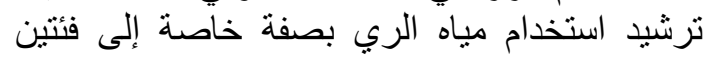
تضم إحداهما الحاصلين علي تدريب ، الرئ ، وتضم الفئة

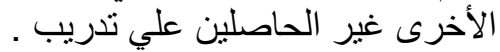

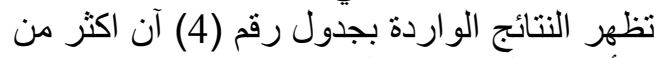

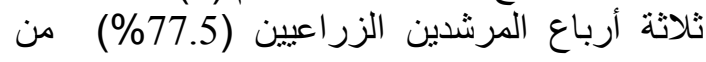

جدول رقم (4) : توزيع المبحوثين وفقا لتلقيهم لدورات تدريبية.

\begin{tabular}{|c|c|c|c|c|}
\hline \multicolumn{2}{|c|}{ أساليب ترشيد استخدام مياة الري مجال } & \multicolumn{2}{|c|}{ 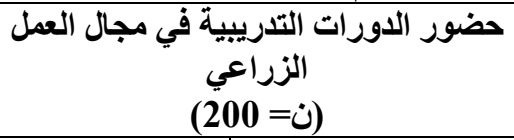 } & \multirow[t]{2}{*}{ فئات التدريب } \\
\hline$\%$ & عدد & $\%$ & عدد & \\
\hline $\begin{array}{l}25.2 \\
74.8\end{array}$ & $\begin{array}{c}39 \\
116\end{array}$ & $\begin{array}{l}77.5 \\
22.5\end{array}$ & $\begin{array}{c}155 \\
45\end{array}$ & المر المتلفين تدريب \\
\hline
\end{tabular}

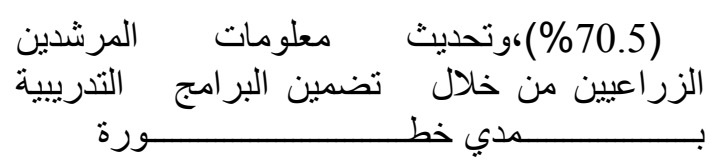

إجمالي عدد المبحوثين قد حصلوا علي تدريب أثناء

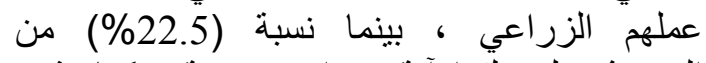
المبحوثين لم يتلقو آية دورات تدريبية ـ كما تنشير 
ذكروا بأنهم برغبون في الحصول علي دورات تدرييية لزيادة معلوماتهم في مجال أساليب ترشيد

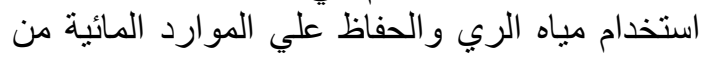

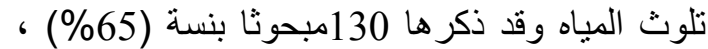
واخيرا زيادة فترات الدورات التهات التدريبية وقد ذكرها

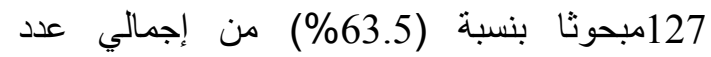

جدول رقم (5) : توزيع المبحوثين وفقا لمقترحاتهم لتحسين مستوي تدريب المرشدين الزراعيين في مجال أساليب ترشيد

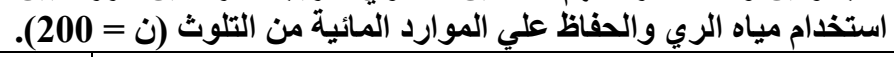

\begin{tabular}{|c|c|c|c|}
\hline$\%$ & عدد & المقترحات & מ \\
\hline 91 & 182 & مياه الري الفرو الحفاظ لحضور دور اتل تدري المييية من التصلوثة في مجال اسـاليب ترشيد استخدام & -1 \\
\hline 88 & 176 & 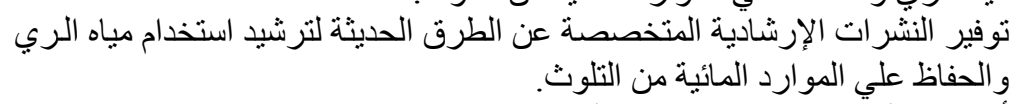 & -2 \\
\hline 79 & 158 & أن يقوم بالتدريب متخصصين في المياه . & -3 \\
\hline 76 & 152 & توفير الإمكانيات و الحوافز الماديّة للمتدربين . & -4 \\
\hline 70.5 & 141 & زيادة فرص التدريب العملي وتوفير وسائل الإيضاح ال & -5 \\
\hline 65 & 130 & تضمين البرامج التدرييية للتّو عيه بددي خطورة تلوثَ & -6 \\
\hline 63.5 & 127 & 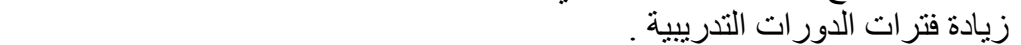 & -7 \\
\hline
\end{tabular}

التلوث في حين ذكر(10\%) منهم بأنهم لا بر غبون.

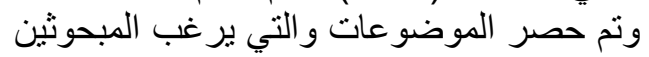

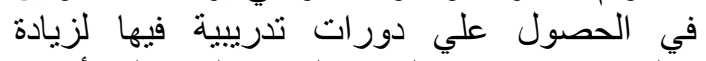
معلوماتهم وحساب النسبة المئوية لهم علية فلي أساس لزباد

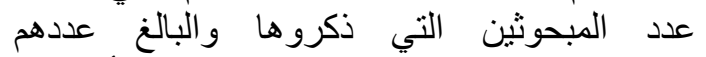

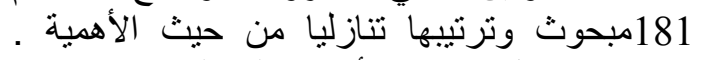

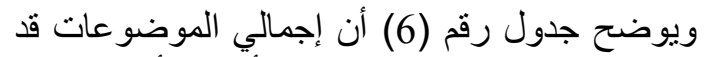

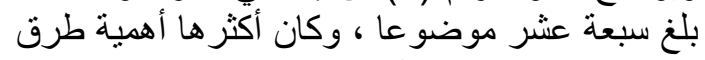

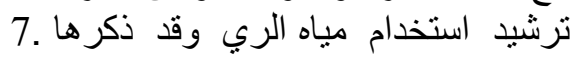

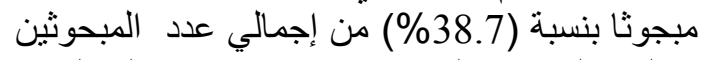

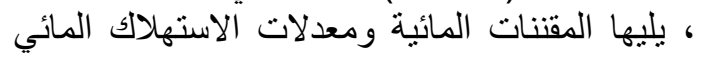

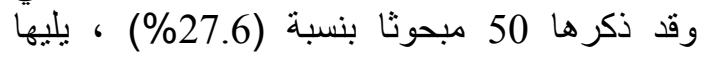
طرق الري الحديث وقد ذكرها

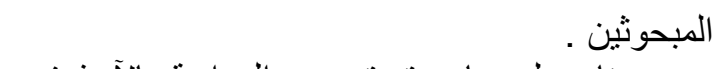
وبناء علي ما سبق توصي الدراسة بالآخذ في

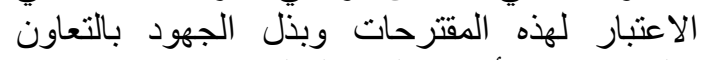

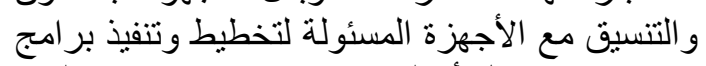
تدريبية في مجال أساليب ترشيد استخدام مياه الرئي

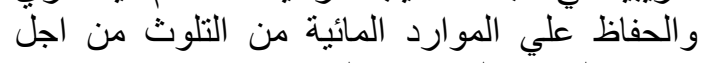

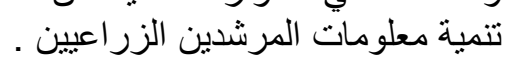

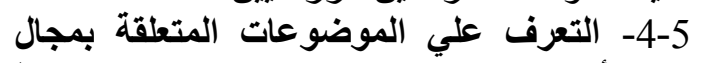

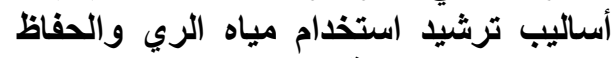

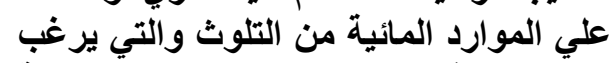

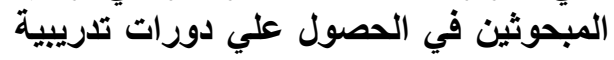

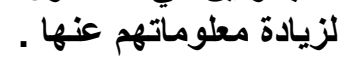
اتضح من النتائج آن غالبية المبحوثين (90\%)

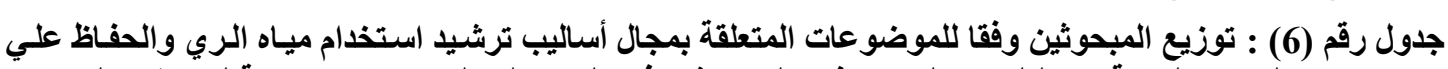

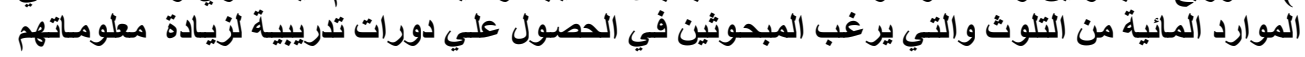

\begin{tabular}{|c|c|c|c|}
\hline \multicolumn{4}{|c|}{ 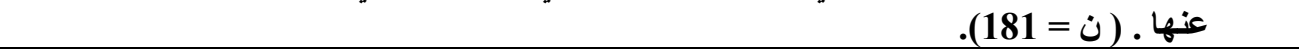 } \\
\hline$\%$ & عدد & 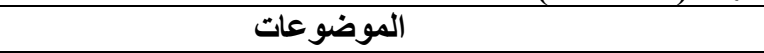 & م \\
\hline 38.7 & 70 & طرق ترشيد استخدام المياه & -1 \\
\hline 27.6 & 50 & المقننات المائية ومعدلات الاستهلاك المائي للمحاصيل & -2 \\
\hline 23.2 & 42 & طرق الري الحديث. . & -3 \\
\hline 16.6 & 30 & طرق التخلص من الحشائش و التي توجد في المجاري المائية. & -4 \\
\hline 13.8 & 30 & كيفية تبطين قنوات الري و الترع و المصارف . . & -5 \\
\hline 13.8 & 25 & المواعيد المثلي لري المحاصيل . & -6 \\
\hline 12.7 & 23 & مدي الضرر الَّي يتسببة ارتفاع منسوب المياه & -7 \\
\hline 11 & 20 & طرق ترشيد مباه الري لمحصولَ الأرز . . & -8 \\
\hline 10.5 & 19 & كيفية استخدام المياه المعالجة . . & -9 \\
\hline 8.3 & 15 & طرق الحفاظ علي الموارد المائية من التلوث . & -10 \\
\hline 7.2 & 13 & طرق التخلص من ورد النيل . . & -11 \\
\hline 6.1 & 11 & تدوير مياه الصرف وكيفية الاستفادة منها . & -12 \\
\hline 4.9 & 9 & كيفية استخدام الميكنة الزر اعية في عملية تطهير القنوات المائية & -13 \\
\hline 4.4 & 8 & طرق الزر اعات الحديثة و التي تقللّ من مياه الري . . . & -14 \\
\hline 2.8 & 5 & كيفية التعامل مع مناوبات الري . . & -15 \\
\hline 1.2 & 4 & الصرف المغطي . . & -16 \\
\hline 1.1 & 2 & الري المحوري وكيفية تشغيله . & -17 \\
\hline
\end{tabular}


الكلية للاحتياج التدريبي المعرفي للمرشدين الزراعيين في مجال أساليب ترشيد استخدام مياه

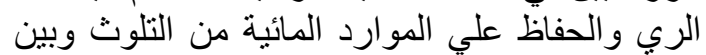
كل من المتغيرات المستقلة المدروسة:

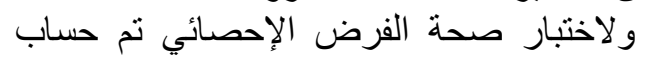
قيمة مربع كآي ومعامل الارتباط البسيط لإنيط لتحديد وجود علاقة معنوية بين الدرجة الارياطية الكلية للاحتياج التدريبي المعرفي للمرشدين الزراعيين في في مجال

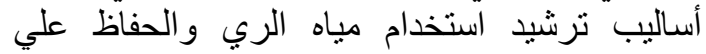

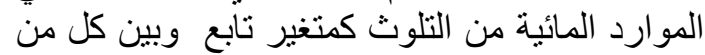

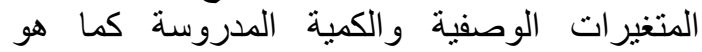
موضح في جدول رقم (8) فقد تنبين:

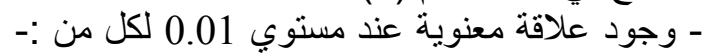

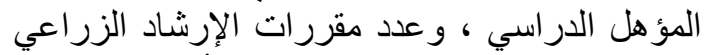

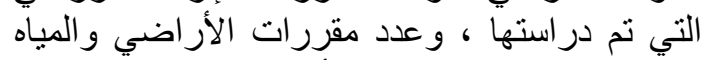

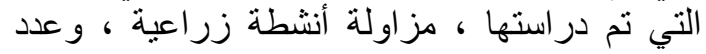

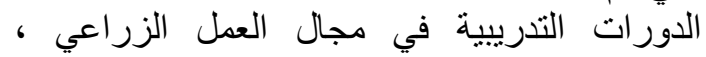

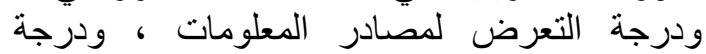
مواجهة معوقات أثناء إرشاد المزارئ الرعين بترشيد ودرية

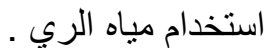

- وجود علاقة معنوية عند مستوي 0.05 لكل من :-

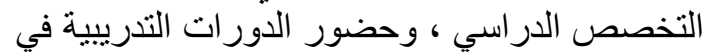

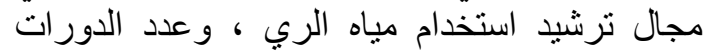

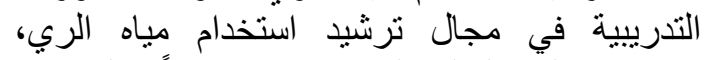

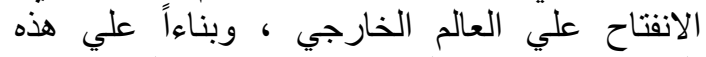

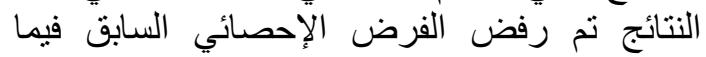

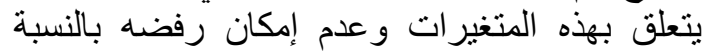

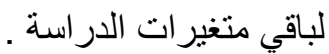

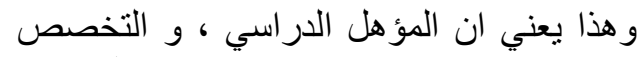

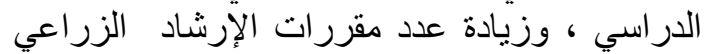

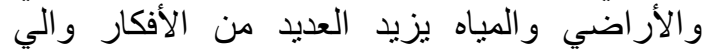
ارتفاع درجة المعلومات ، بلإلإضافة لزيادة الرئ الرغبة

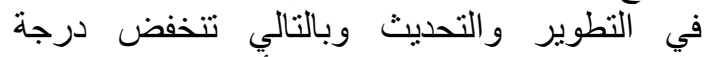
احتياجاتهم التدريبية في مجال أساليب نرشيد مياه

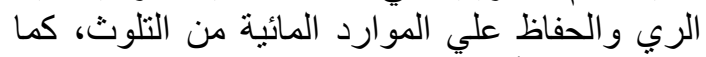

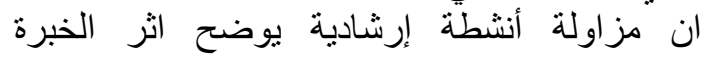

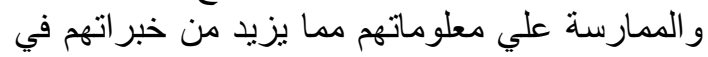

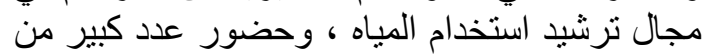
الدورات التدرييية في مجال العمل الزر اعي وتئي وترشيد استخدام مياه الري يؤدي إلى دئ تكوين رصيد الزيد معرفي وبالتالي ارتفاع درجة المعلومات ولئ وزيادة مستواته

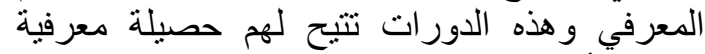
كبيرة الأمر الذي ينعكس علي التئي التياجاتهم التدريبية

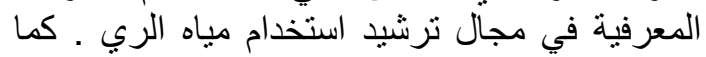

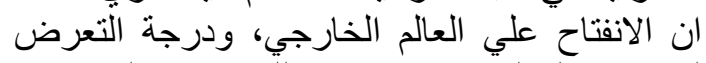

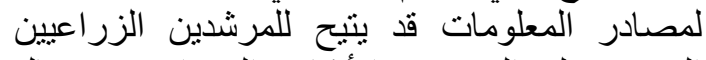

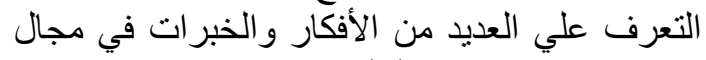
ترشيد استخدام مياه وبالتالي

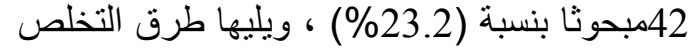

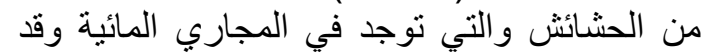

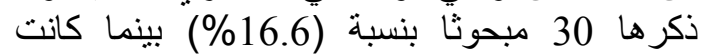

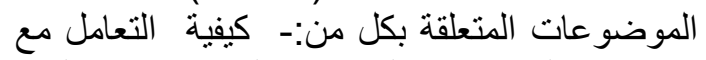

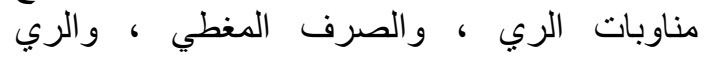

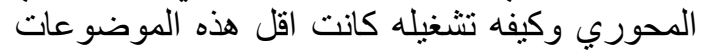

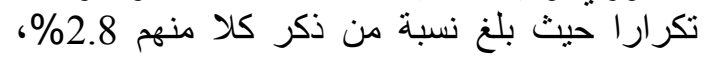

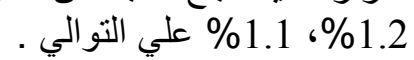
ولذا توصي الدراسة بالأخذ في الاعتبار لهذه

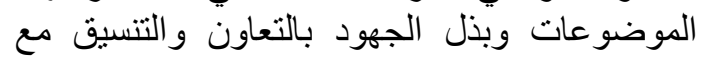
وزارة الأشغال العامة و الموارد المائية بدعم الروابط

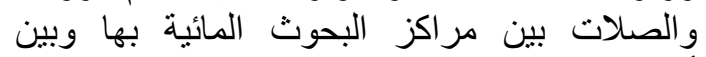

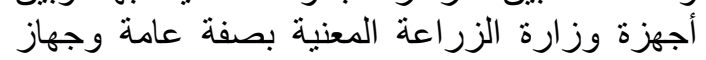

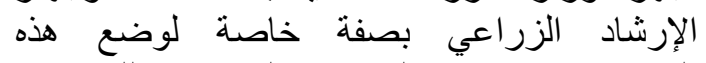

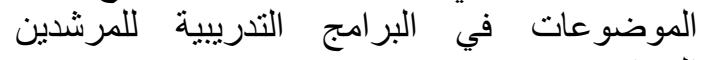

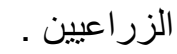

5-5-5 الأنثطة الإرشادية التي قام بها المبحوثين في

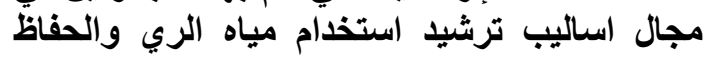

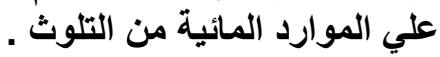

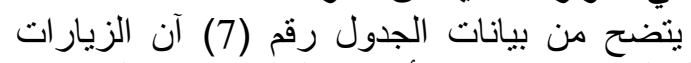

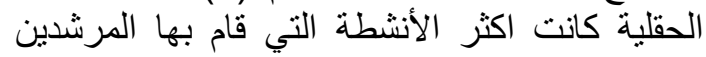

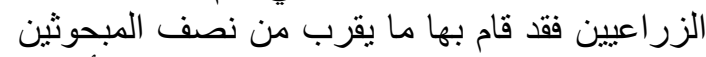

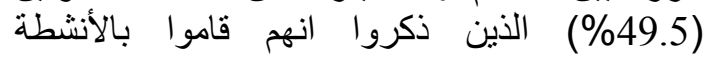

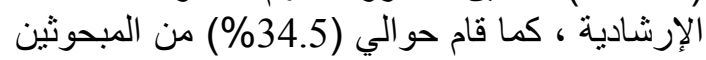
بعقد ندوات إرشادية بينما (30\%) (34\%) من المبحو المبحوثين

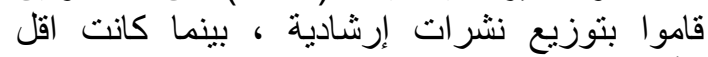

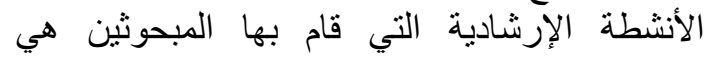

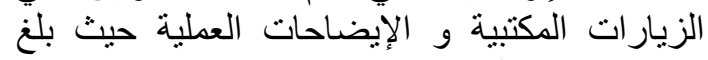
نسبة من ذكر كل منهما 5.0\% الإيضاحات 0.5 \%

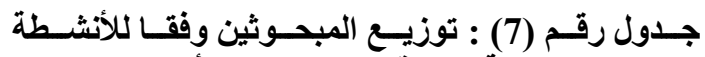

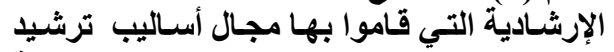
استخدام مياه الّري والحفاظ علي الموارد المائية

\begin{tabular}{|c|c|c|c|}
\hline \multicolumn{4}{|c|}{ من التلوث ـ ( ن = 200). } \\
\hline$\%$ & عدد & الأنثطةٌ الإرشادية & R \\
\hline 49.5 & 99 & الزيار ات الحقلية ـ & -1 \\
\hline 34.5 & 69 & عقد ندو ات إرشادية . & -2 \\
\hline 30 & 60 & توزيع نشر ات إرشادية. & -3 \\
\hline 5.0 & 10 & زيار ات مكتبية . & -4 \\
\hline 0.5 & 2 & إيضاحات عملية . & -5 \\
\hline
\end{tabular}

6-5- العلاقة بين الدرجة الكلية للاحتياج التدريبي المعرفي للمرشدين الزين الزراعيين في مجال أساليب

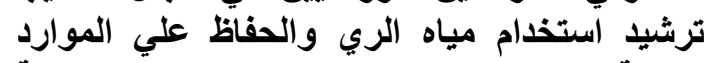

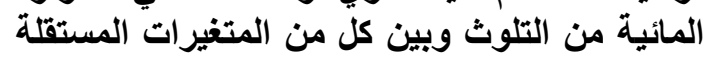
المدروسة. لاختبار صحة الفرض البحثي تم وضع الفرض الإحصائي التالي : لا توجد علاقة معنوية بين الدرجة الدرضة 
جدول رقم (8) : العلاقة بين الارجة الكلية للاحتياج التدريبي المعرفي للمرشدين الزراعيين في مجال أساليب ترشيد استخام مياه الري و الحفاظ علي الموارد المائية من التلوث وبين كل من المتغيرات المستقلة المدروسية.

\begin{tabular}{|c|c|c|c|c|c|}
\hline الأرتباط معامل البسيط & قيمة مربع كآي & المعياري & المسابي & المتغيرات المستقلة & r \\
\hline 0.017 & ----- & 4.93 & 47.2 & السن. & 1 \\
\hline$\ldots .$. & 4.182 & 0.25 & 1.6 & النشأَة. & 2 \\
\hline ....... & $* * 11.213$ & 0.48 & 1.35 & 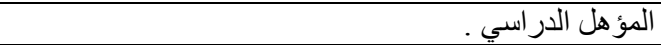 & 3 \\
\hline ...... & $* 9.688$ & 1.72 & 2.2 & التخصص الدراسي . & 4 \\
\hline$* * 0.188-$ & $\ldots .$. & 2.35 & 1.9 & عدد مقرر ات الإرشاد الزر اعي التي تم در استها & 5 \\
\hline$* 0.229$ & ...... & 1.47 & 1.1 & عدد مقرر ات الأر اضي و المياه التي تم در استها & 6 \\
\hline$\ldots .$. & $* * 24.779$ & 0.39 & 1.81 & مز اولة أنشطة زراعية . & 7 \\
\hline $0.077-$ & $\ldots .$. & 1616 & 1037 & المساحة المنزر عة في منطقة عمل المرشد الزراعي . & 8 \\
\hline $0.062-$ & $\ldots .$. & 221 & 565.3 & عدد الزر اع المشرف عليهم. . & 9 \\
\hline $0.072-$ & $\ldots .$. & 7.49 & 21.18 & مدة الخدمة بالعمل الزراعي. & 10 \\
\hline 0.047 & ...... & 6.69 & 15.10 & مدة الخدمة بالعمل الإرشادي الزر اعي . & 11 \\
\hline & 2.100 & 0.42 & 1.77 & حضور الدورات التندييية في مجال العمل الزراعي . & 12 \\
\hline **0.379- & & 1.70 & 1.86 & عدد الدورات التدرييية في مجال العمل الزراعي. & 13 \\
\hline ..... & $* 7.233$ & 0.48 & 1.36 & الري. رضور الدورات التذرييية في مجـال ترشيد استخدام ميـاه & 14 \\
\hline$* 0.154-$ & . . & 1.15 & 0.65 & عدد الدورات التندييية في مجال ترشيد استخدام مياه الري. & 15 \\
\hline ..... & 1.641 & 0.29 & 1.90 & الري. الرغبة في زيادة المعـارف في مجال ترشيد استخدام مياه & 16 \\
\hline$* 0.170$ & ..... & 3.18 & 15.94 & الانفتاح علي العالم الخارجي . & 17 \\
\hline **0.220- & & 3.05 & 16.99 & درجة التعرض لمصادر المعلومات . . المبات & 18 \\
\hline ..... & 2.529 & 0.50 & 1.49 & مز اولة أنشطة إرشادية في مجال ترشيد استخدام مياه الري. & 19 \\
\hline 0.123 & --- & 1.27 & 5.58 & عدد الأنشطة الإرشادية فى مجال ترشيد استخدام مياه الرى & 20 \\
\hline---- & $* * 28.649$ & 0.49 & 1.39 & 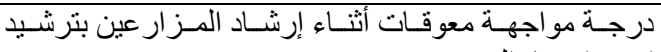 & 21 \\
\hline
\end{tabular}

ذكر (39.5\%) من المبحوثين بأنة لم تقابلهم معوقات

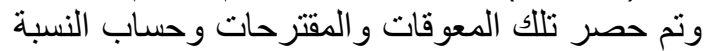

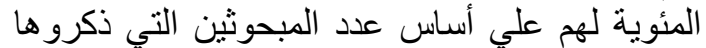

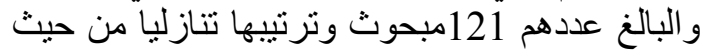

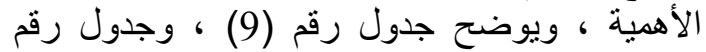

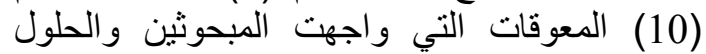

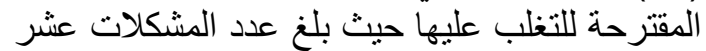
مشكلات والحلول ثلاثة عشر، وكان أكثرها أهمية

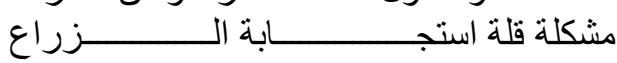

تنخفض درجة احتياجاتهم التدريبية المعرفية في

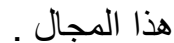

7-5 - المعوقات التي تواجه المبحوثين عند توعية الزراع بأساليب ترشيد استخدام مياه الري والئ والدفاظ علي الموارد المائية من التلوث والئي والحلول المقترحة

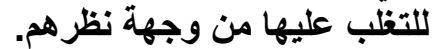

تثير النتائج آن غالبية المبحوثين (60.5\%)

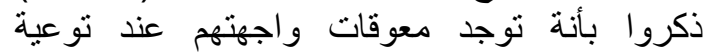

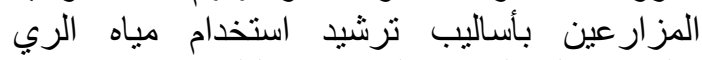
و الحفاظ علي الموارد المائية من التلوث ، في حين

جدول رقم (9) : المعوقات التي تواجه المبحوثين عند توعية الزراع بأساليب ترشيد استخدام مياه الري والحفاظ علي

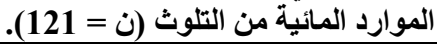

\begin{tabular}{|c|c|c|c|}
\hline \multirow[b]{2}{*}{$\%$} & \multirow[b]{2}{*}{ عدد } & \\
\hline & & المعوقات & م \\
\hline 49.6 & 60 & من التلوثة استجة الزر اع للتوصيات المتعلقة بأساليب ترشبد استخدام مياه الري و الحفاظ علي الموارد المائية & 1 \\
\hline 46.3 & 56 & ارتفاع تكاليف أساليب الري الحديث. & 2 \\
\hline 37.2 & 45 & قلة النشر ات الإرشادية المتخصصة في مجال ترشيد استخدام مياه الري . & 3 \\
\hline 24.8 & 30 & عدم صيانة شبكة الري و عدم تطهير التّرع و المصارف . . & 4 \\
\hline 20.7 & 25 & عدم انتظام فتر ات مناو بات الري . . ع ع & 5 \\
\hline 19.8 & 24 & كبر حجم المساحة المنزر عة أرز. & 6 \\
\hline 12.4 & 15 & عدم فرض عقوبات أو غرامات لمخالفي الري. & 7 \\
\hline 9.9 & 12 & كبر حجم المساحة التي يشرف عليها المرشد الزر اعي. & 8 \\
\hline 4.1 & 5 & كثرة القنو ات و المصارف في الحقول و عدم الاهنمام بها . & 9 \\
\hline 1.7 & 2 & عدم وصول المياه في فنترة احتباج النبات و الي نهايات الترع. & 10 \\
\hline
\end{tabular}


جدول رقم (10) : مقترحات المبحوثين للتظلب علي المعوقات التي تواجههم عند توعية الزراع بأساليب ترشيد استخدام مياه

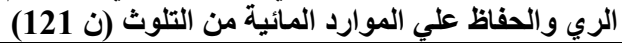

\begin{tabular}{|c|c|c|c|}
\hline$\%$ & عدد & الحلول & م \\
\hline 33.1 & 40 & عمل تجارب وحقول إرشادية تطبق بها أساليب ترشيد مياه الري . & 1 \\
\hline 26.4 & 32 & زليادة عدد النشر ات الإرشادية المتخصصة في ترشيد استخدام مياه الري و المقننات المائية & 2 \\
\hline 18.2 & 22 & عقد ندوات إرشادية لعلاج الأفكار الخاطئة و القديمة. . & 3 \\
\hline 16.5 & 20 & عمل دور رات تدريبية لتحديث معلومات المرشدين الزر اعية فيما يتعلق بترشيد مياه الري. & 4 \\
\hline 16.5 & 20 & زيادة التو عية الإعلامية فيما يتعلق بترشيد استخدام مياه الري عن طريق الإذاعة و التللفزيون. & 5 \\
\hline 14 & 17 & 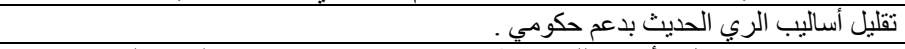 & 6 \\
\hline 12.4 & 15 & القتين زر الزرة اعحة للالتز ام بمساحات الأرز وذلك طريق المحددة بالدورة غرامات حازمة علي مخالفي & 7 \\
\hline 9.1 & 11 & تقليل مساحة حجم الأرز التي يشرف عليها المرشد الزراعي. & 8 \\
\hline 7.4 & 9 & تنظيم ومواءمة مناوبات الري بين الزراع . . & 9 \\
\hline 6.6 & 8 & تحديد انسب مو اعيد للري حسب احتياج النبات . & 10 \\
\hline 4.9 & 6 & زيادة منسوب المياه للوصول إلى نهايات الترع . & 11 \\
\hline 4.1 & 5 & أستخدام الصرف المغطى لتقليل الفو اقد. & 12 \\
\hline 0,8 & 1 & فرض غر امات حازمة لمخالفى الرى . & 13 \\
\hline
\end{tabular}

المساحة التي يشرف عليها المرشد الزراعي ـ ، بينما

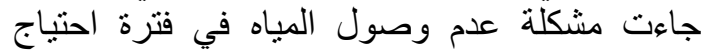

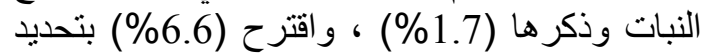

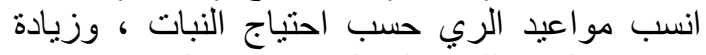
منسوب المياه للوصول الري نهايات الترع وذكرها . (\%

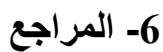

- أبو السعود ، خيري حسن (2002).أمثلة لرسائل

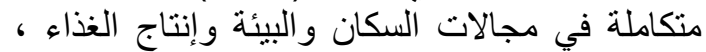

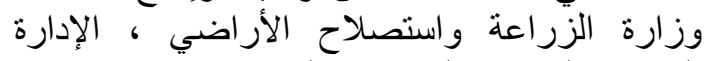
المركزية للإرشاد الزراعي ،اعية الجيزة . - أخبار البيئة (2004).

http://www.4eco.com./2004/01/04 index.html.35k.

الزراعي بمديرية الزراعة - إدارة الإرشاد محافظة الدقهلية (2007) ـ بيانات غير منشورة الزية

$$
\text { - الأهالي (2007)، ترشيد المياه في مصر. }
$$

http://www.alahaly.com/articles/07/-0214/1314.opn10.htm

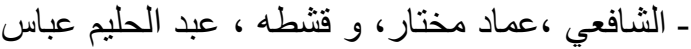

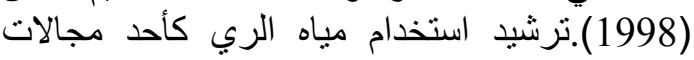

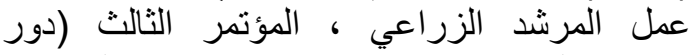

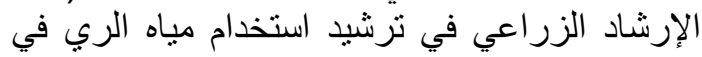

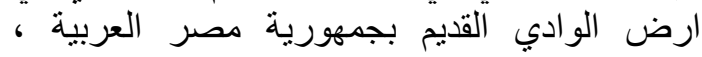

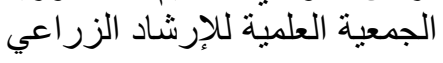

لللتوصيات المتعلقة بأساليب ترشيد استخدام مياه الري و الحفاظ علي الموارد المائية من التلوث حيث التئ ذكرها

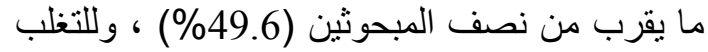

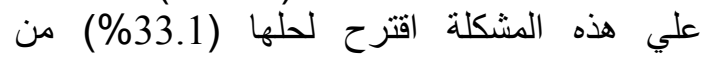
المبحوثين بعمل تجارب وحقول إرشادية تطبق بها

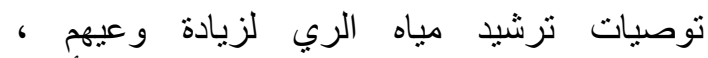
و(18.2\%) بعقد ندوات إرشادية لعلاج الأفكار

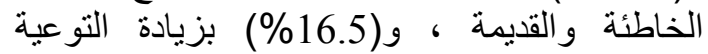
الإعلامية فيما يتعلق بترشيد استخدام مياه الري عن بادئ

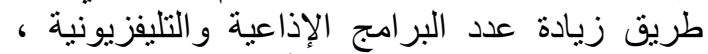

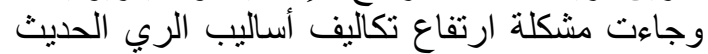

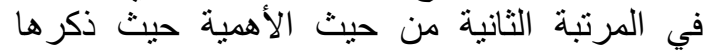
(46.3\%) من إجمالي المبحوثين و اقترح المبحوثين

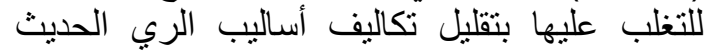

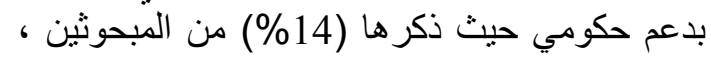

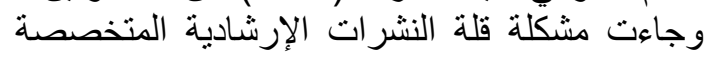

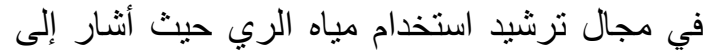

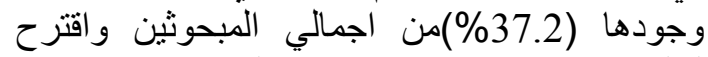

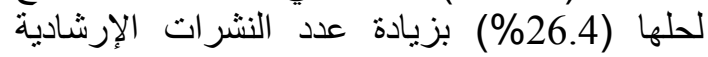

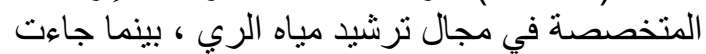

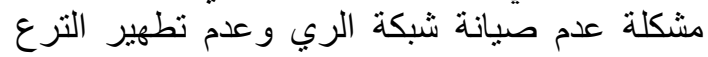
و المصارف حيث ذكرها (24.8\%) من المبحوثين ،

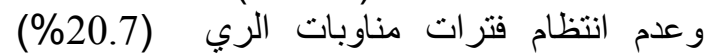
و اقترح (6.6\%) بتنظيم ومواءمة منات وناوبات الري بين

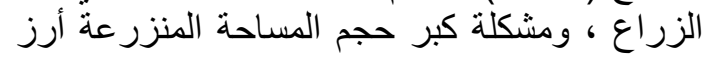

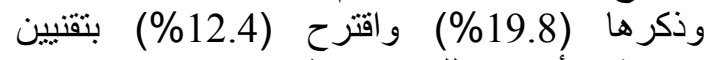

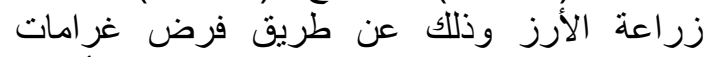

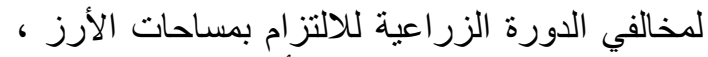

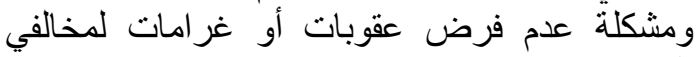

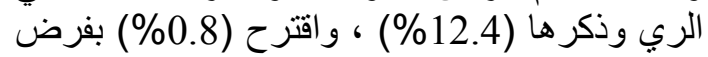

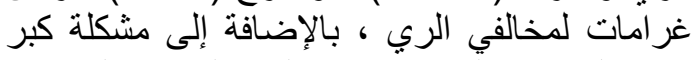
حجم المساحة التي يشرف الري عليها المرشد الزئة الزراعي وذكرها (9.9\%) ، واقترح (9.1\%) بتقليل حجم الزئ 
الفيوم ، رسالة ماجستير ، كلية الزراعة ، جامعة

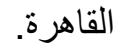
- عنير، نصر جميل (2007)، ندوة الإرشاد ألا

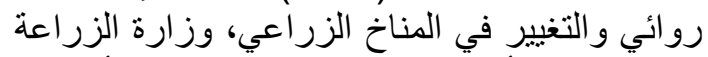

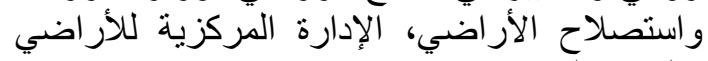

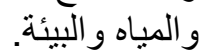

ـ ق قتشطه، عبد الحليم عباس، و الثـافعي ،عمـاد مختار

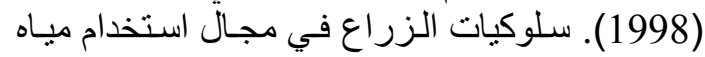

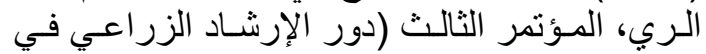

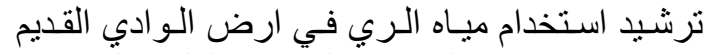

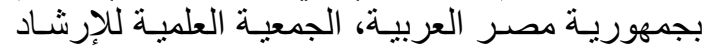

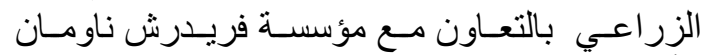

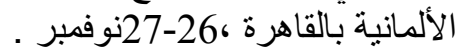

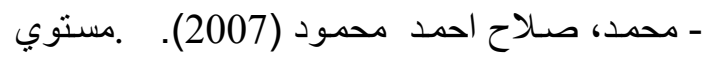

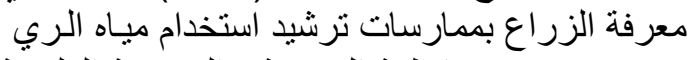

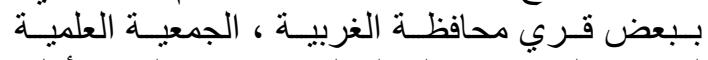
للإرشاد الزر أعي ، المجلد الحادي عشر، العدد الأول. http://www.Almyah. - منتديات المياه (2008).

Com/vb/sprintttthread.php? t29213/3/2008

Boydell T.H. (1990).A Guide to the identification of Training Needs, B.A.C.I, E., UK.

Krejcie,R.and Morgan D.W. (1970) ." Determining Sample Size for Research Activities in Education and Psychological Measurement, vol. (30), Publishished by College Station, Durham, North Carolina, U.S.A.

Peterson R., (1992) .Training needs analysis in the workplace. Institute of Training \&Developmnet, Kogan page,Uk.

Radhakrishna R., and Martin, Mary (1999). "Program evaluation and accountability training needs of agriculture extension agent ", Journal of extension, Vol.37, N.3.

http:// www. Joe.org/1999jun/rb1.htm1.
بالتعاون مع مؤسسة فريدرش ناومان الألمانية

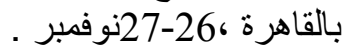

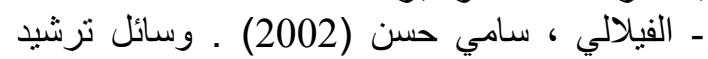
استخدام مياه الري في الزر اعة المي المصرية ، الإدارة المركزية للأراضي والري فالزياه و البيئة ، وزئة ، الإدارة

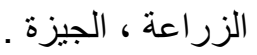

http://www. Idrc.ca/uploads/users/10637285101Egypt-Ministry AgricultureRationalization.doc5/5/2007.

ـ الغاوي، محمد أمين (2005)، دور الزئ الإرشاد الزراعي في ترشيد استخدام الموارد المائية بواحة الإنة

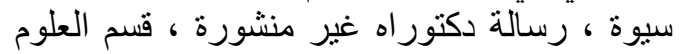

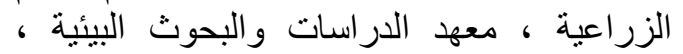

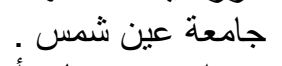

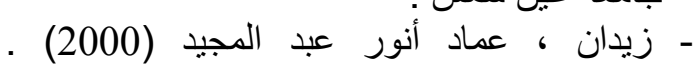
الاحتباجات التدريبية للمرشدين الزرانيان اعبين في مجال

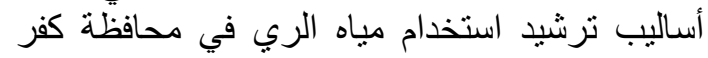

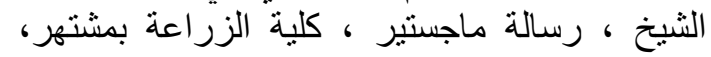
جامعة الزقازيق .

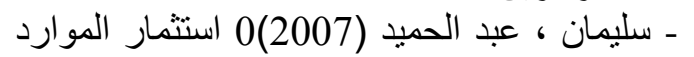

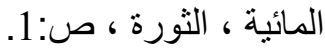
http://www.thawra.alwahda.gov.sy/huttabas p? = 262546.2007.04.11/234918-62k

- شرشر، حسن علي (1998). بعض العوامل

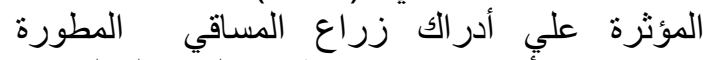

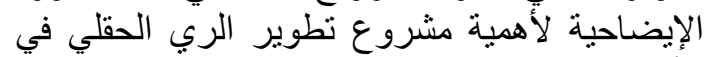

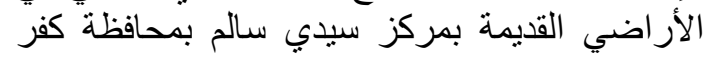

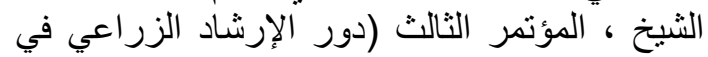

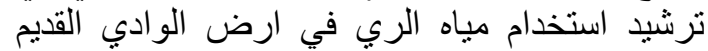

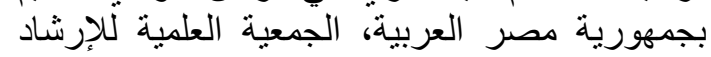

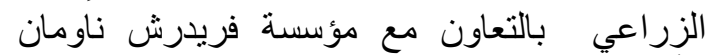

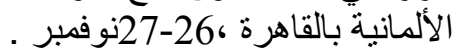

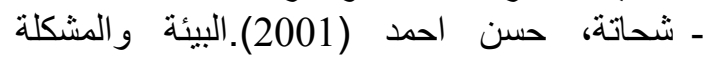
السكانية، الدار العربية للكتاب ، الطبعة الأولى.

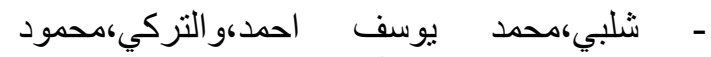

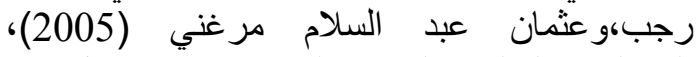
المتطلبات التعليمية لثباب الخريجين في مجال نظم

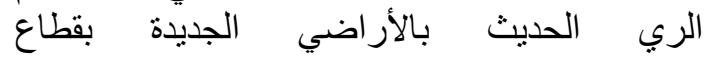

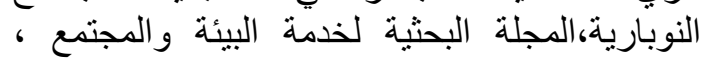
لجمعية العلمية حماية البيئة بالثرقية لبية ،مجلد

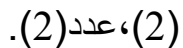

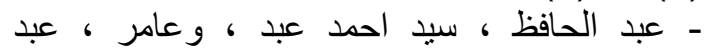

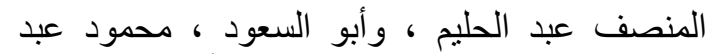

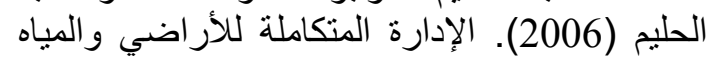

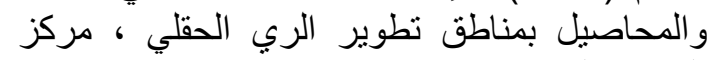

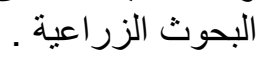
- علي ، عماد الحسيني (2000).معلومات الزئ المرشدين

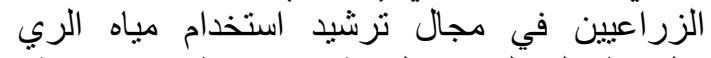

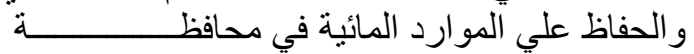

